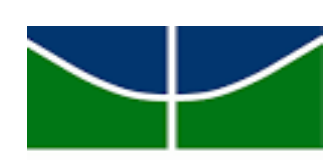

Universidade de Brasília

Univeridade de Brasília - UNB

Instituto de Artes Visuais

Programa de Pós- Graduação em Arte (PPG - ARTE - UNB/UAB - CAPES)

CURSO DE ESPECIALIZAÇÃO EM EDUCAÇÃO E PATRIMÔNIO CULTURAL E ARTÍSTICO - UNB/ UAB

\title{
A INTERFACE ENTRE AS ARTES VISUAIS E AS POÉTICAS DA CENA
}

VLADIMIR CORRÊA FONSECA

ORIENTADORA: SANDRA REGINA SANTANA COSTA

BRASÍLIA/ 2018 


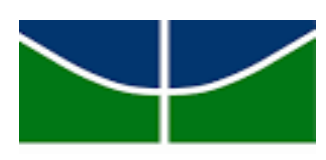

\author{
Universidade de Brasília \\ Univeridade Brasília - UNB \\ Instituto de Artes Visuais
}

Programa de Pós- Graduação em Arte( PPG - ARTE - UNB/UAB- CAPES) para o curso de pos- graduação, Lato Senso, em Especialização em Educação, Patrimônio Cultural e Artístico

VLADIMIR CORRÊA FONSECA

\title{
A INTERFACE ENTRE AS ARTES VISUAIS E AS POÉTICAS DA CENA
}

Monografia apresentada ao Curso de Especialização em

Educação e Patrimônio Cultural e Artístico - PPG -

Arte - UNB/UAB - CAPES

Orientadora: Sandra Regina Santana Costa 
TERMO DE APROVAÇÃO

VLADIMIR CORRÊA FONSECA

\section{A INTERFACE ENTRE AS ARTES VISUAIS E AS POÉTICAS DA CENA}

Monografia aprovada como requisito parcial para obtenção do grau de Especialista do Curso de Educação e Patrimônio Cultural e Artístico - UNB/UAB.

Apresentação ocorrida em /__ $/ 2018$.

Aprovada pela banca formada pelas professoras:

NOME DA ORIENTADORA: Prof ${ }^{\mathrm{a}}$. Dra ${ }^{\mathrm{a}}$. Sandra Regina Santana Costa

NOME DA EXAMINADORA: Prof ${ }^{\mathrm{a}}$. Dr ${ }^{\mathrm{a}}$. Verônica Guimarães Brandão da Silva

NOME DO ALUNO: Vladimir Corrêa Fonseca 
Dedicado a minha mãe, Olga Nicola Fonseca, que me estimula a ser sempre um homem apaixonado pelo que realiza.

Dedicado aos queridos e queridas alunos(as) da Escola Estadual Antônio Olympio, bem como a minha orientadora, Sandra Regina Santana Costa, pela sabedoria, pelo estímulo e força. 


\section{AGRADECIMENTOS}

Para os queridos da Escola Estadual Antônio Olympio assim como para a minha tutora Verônica Brandão, para meus amigos: Eduardo Ramos, Garibaldi Costa, Jayme Paez, Denise Corrêa e para os professores e colegas, pelo apoio ao longo do curso.

A inspiração de Graciliano Ramos: "Comovo- me em excesso, por natureza e por ofício. Acho medonho alguém viver sem paixões." 


\section{RESUMO}

Nesse trabalho valorizamos a visualidade e reafirmamos a importância da educação patrimonial, cultural e artística dentro da Escola Estadual "Antônio Olympio" (Barretos / São Paulo) sobre os mais diversos aspectos, instigando alunos e alunas através de uma oficina teatral, incluindo uma leitura dramática e entrevistas, a vivenciarem e repensarem a interface entre as artes visuais e as poéticas da cena. É necessário argumentar que propomos não apenas um estudo de imagens por meio das obras de Candido Portinari e de Graciliano Ramos, contando também com as reflexões de Augusto Boal, Maciel e Barbato, Pelegrini e outros(as) autores(as) mas também investigar o homem e um encontrar de condições internas de mudanças que permitam a transformação de seu histórico pessoal e social. Urge enfrentar desafios, e buscar questionamentos e discussões sobre a nossa cultura hegemônica, e suas ações efetivas, dentro e fora da escola que nos permita rever e repensar o ser humano, além de sua pseudo aparência, resgatando-o holisticamente.

Palavras-Chave: Integralidade, Educação Patrimonial, Interdisciplinaridade, Promoção e qualidade de vida. 


\begin{abstract}
In this work we value visuality and reaffirm the importance of heritage, cultural and artistic education (within the State School "Antônio Olympio" - Barretos / São Paulo) on the most diverse aspects, encouraging students through a theatrical workshop (including a reading dramatic and interviews) to experience and rethink the interface between the visual arts and the poetics of the scene. It is necessary to argue that we propose not a study of images, through the works of Candido Portinari and Graciliano Ramos, also counting on the works of Augusto Boal, Maciel and Barbato, Pelegrini and other authors to investigate the man and a finding of internal conditions of changes that allow the transformation of his personal and social history. It is urgent to face challenges, and to seek questions and discussions about our hegemonic culture, and its effective actions, inside and outside the school that allow us to review and rethink the human being, besides his pseudo appearance, rescuing him holistically.
\end{abstract}

Key words: Integrality, Patrimonial Education, Interdisciplinarity, Promotion and quality of life. 
SUMÁRIO

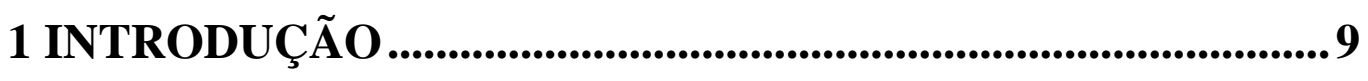

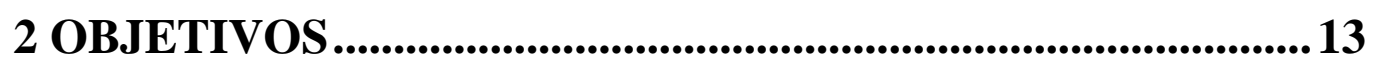

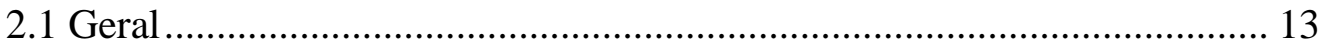

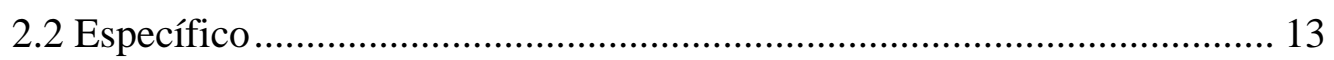

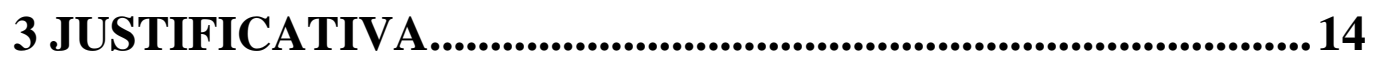

4 FUNDAMENTAÇÃO TEÓRICA ..........................................18

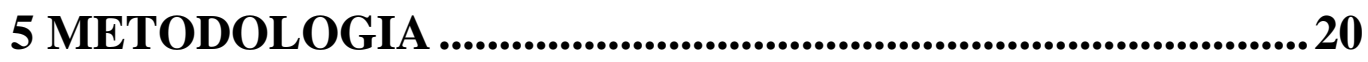

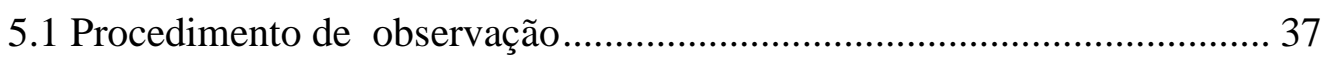

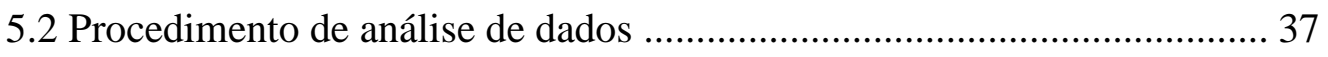

6 ANÁLISE E DISCUSSÕES DE RESULTADOS .......................42

7 CONSIDERAÇÕES FINAIS ........................................................... 44

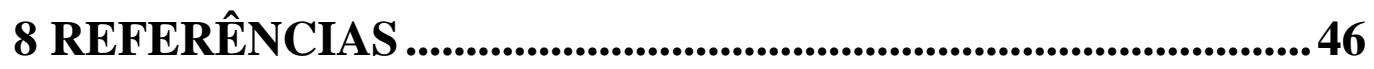

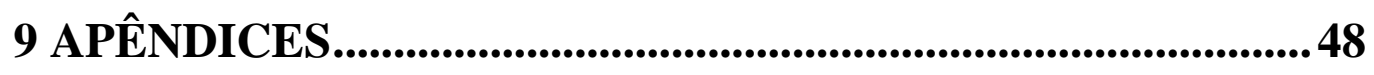

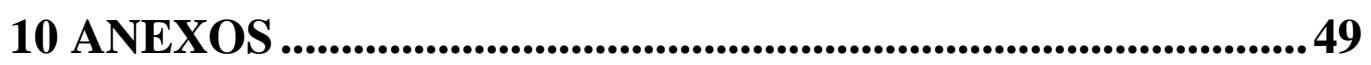




\title{
1 INTRODUÇÃO
}

Ao falarmos em teatro ou teatralização dentro das Instituições escolares (particulares ou públicas) somos levados geralmente (pelas instituições) em reduzir esta arte apenas à encenações, ou produções artísticas, geralmente realizadas por alunos(as) com o único propósito de preencher um calendário escolar calcado em datas comemorativas. Entretanto precisamos instigar à busca pela autonomia, pela arte e por mudanças no cotidiano. Desta forma, urge divulgar que o teatro, segundo Boal:

\begin{abstract}
no sentido mais arcaico do termo, porém, teatro é a capacidade dos seres humanos (ausente nos animais) de se observarem a si mesmos em ação. Os humanos são capazes de se ver no ato de ver, capazes de pensar suas emoções e de se emocionarem com seus pensamentos. Podem se ver aqui e se imaginar adiante, podem se ver como são agora e se imaginar como serão amanhã (BOAL, 2009, p. 14).
\end{abstract}

Repensar nossas vivências e possibilitar reflexões sobre a importância da leitura, da arte cênica, da cultura e das artes visuais em nossas vidas é um privilégio, por isso destacamos o teatro como ferramenta pedagógica dentro da Escola Estadual Antônio Olympio (Barretos- São Paulo). Este projeto surge por meio de um convite feito em 2016, pela instituição citada, para que fosse realizada uma oficina cultural tendo a duração de um ano, com o apoio da direção da instituição e parceria da professora de artes visuais, juntamente com os alunos do ensino fundamental - com os(as) alunos(as) dos oitavos anos e primeiras séries do ensino médio.

Em 2016 e em 2017, por meio das experiências com os(as) alunos(as) ficou estabelecido que não somente o projeto deveria ter continuidade em 2018, mas ser levado a cena, com os(as) novos(as) alunos e alunas do $8^{\circ}$ ano $\mathrm{A}$, do $8^{\circ}$ ano $\mathrm{C}$ e o $8^{\circ}$ ano D. Após discutirmos com os(as) alunos(as) e com a professora de Língua Portuguesa, que participa do projeto desde 2017, reafirmamos que a Instituição citada não reforça [...] "uma atitude de subvalorização da leitura do texto escrito e mais especificamente do livro. Desse modo, uma consequência coerente com essa observação é a constatação da ausência, ou subutilização, de livros nas nossas escolas." (MACIEL; BARBATO, 2015, p. 124).

A fim de refletir as possibilidades em trabalharmos, mais especificamente, com a obra "Vidas Secas" de Graciliano Ramos" e com as obras, a serem escolhidas, de Cândido

\footnotetext{
${ }^{1}$ Graciliano Ramos de Oliveira (1892-1953) foi um dos mais importantes escritores do início do século XX, sendo que o romance "Vidas Secas" foi sua obra de maior destaque. (N.A.)
} 
Portinari $^{2}$, este trabalho pretende realizar uma leitura dramática com apenas o grupo formado pelos alunos dos oitavos anos selecionados, fazendo-os refletir sobre a interdisciplinaridade entre as artes visuais e as artes cênicas.

A leitura e escrita são produtos de interações sociais e a oficina reitera esta afirmativa, optando por obras que despertem não apenas reflexões sobre a nossa realidade, mas também a criação de um diálogo, principalmente entre escola, família e comunidade, pois as apresentações, que terão duas sessões dentro da Instituição propõem um debate ao final das mesmas, ambas gratuitas e já experimentadas em 2016 e 2017.

As autoras e autores escolhidos(as) no trabalho, nos fazem repensar que professores e arte-educadores, ao buscar uma pedagogia qualitativa e trabalhos práticos, devem estar atentos a todos os materiais disponíveis, incluindo artes visuais, tecnologias assistidas, e demais recursos que possibilitam a inclusão de todos os(as) alunos(as), apresentando ou não dificuldades em seu aprendizado, quer de ordem psicológica, mental ou motora. Importante ressaltar, ainda, que as autoras e autores, independentemente de terem suas reflexões citadas ou não, serviram de inspiração para a criação de figurinos, de cenografia, de desenho de luz, entre outros.

Sendo assim, acreditamos que é necessário e possível experimentar e vivenciar "A interface entre as artes visuais e as poéticas da cena", não apenas na Instituição citada, mas em qualquer instituição, que prioriza o homem, e o vê como um ser pensante e atuante.

Para complementar, ressaltamos também que a intenção do projeto não é aprofundar o estudo das artes visuais, mas ter uma noção clara sobre o que é visão e visualidade quando estamos propondo uma “ Interface entre as artes visuais e as poéticas da cena " pois não pretendemos apenas ilustrar o texto de Graciliano Ramos com as obras de Candido Portinari, por isso, urge provocar alunos e alunas a uma reflexão mais profunda e construir um diálogo não somente entre as imagens e o texto, mas uma compreensão também ideológica, pois a arte é política por excelência.

\footnotetext{
${ }^{2}$ Cândido Portinari (1903-1962) foi um pintor brasileiro, um dos principais nomes do Modernismo cujas obras alcançaram renome internacional. (N.A.)
} 


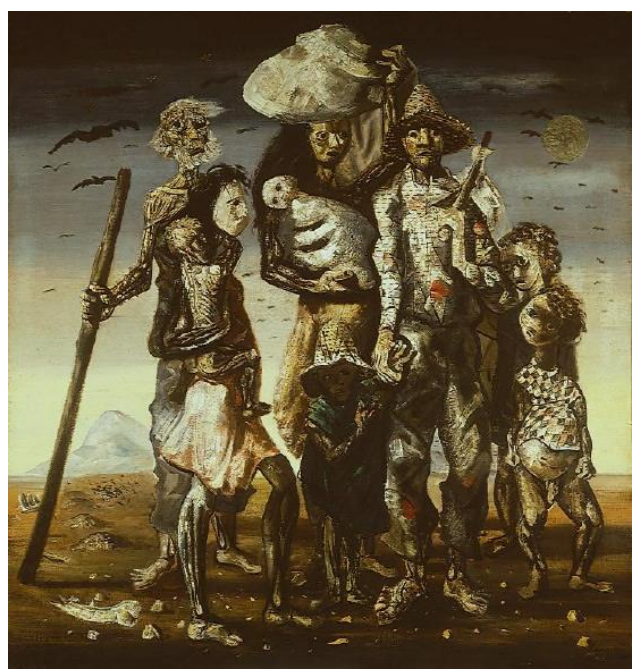

Figura 1- "Os retirantes" - Fonte: http://www.f2mvirtual.com.br/abca/n26/imgs/portinari3.jpg

Diante disso, explicitamos que não podemos instigar práticas colonizadoras, onde existe uma hegemonia e um domínio do saber (pertencentes apenas a professores) mas sim a criação de uma relação dialógica e rica, que leva em consideração a prática e a vivência do outro, pois o teatro é uma prática coletiva e transformadora e propõe também superar limites, por isso, citamos, Maciel e Barbato:

[...] onde se quer assistencialismo, se troca por empoderamento; onde se quer pena, se troca por respeito; onde ser quer analfabetos deficientes, se troca por sujeitos que por acaso têm uma deficiência, mas que não os impedem de serem letrados e atuantes (MACIEL; BARBATO, 2015, p. 50)

É necessário reforçar sempre que a escola deve refletir e propor ações mais inclusivas e menos ditatoriais, pois a busca pela autonomia, tanto no aprendizado, como no cotidiano é possível.

O processo construtivo que, com certeza, pode ser proporcionado pelas atividades a serem desenvolvidas, por meio de exercícios de corpo, de voz, memorização, improvisação livre e improvisada, jogos teatrais e dramáticos, baseia- se no pressuposto de que estas são fatores primordiais de desenvolvimento e aprendizagem.

Todo esse conteúdo vem de acordo com as necessidades e experiências que existiam inicialmente, tanto pela direção e coordenação pedagógica da instituição assim como pelos (as) alunos(as) desta instituição que encontra no teatro a busca pela própria voz e estímulo para o aprimoramento e desenvolvimento artístico e pessoal. 
Sendo assim, acreditamos ser possível experimentar e vivenciar A interface entre as artes visuais e as poéticas da cena não apenas dentro da Escola Estadual "Antônio Olympio" mas em qualquer instituição que prioriza o homem e a busca por uma educação, onde os(as) alunos(as) possam ser os protagonistas de seu processo de aprendizagem e entendam que é possível também uma parceria entre escola, família, órgãos governamentais, entre outros. Acreditamos que investir na formação de profissionais, independentemente da área de atuação, é um passo ímpar para possibilitar uma sociedade e uma educação menos brutalizante e mais inclusiva.

Precisamos resgatar o teatro dentro das Instituições como um direito do cidadão. Neste sentido, segundo nos atesta Japiassu (2001; 28 e ss.), o teatro é uma forma de expressão capaz de articular aspectos plásticos e linguísticos e, em sua prática, transforma o educando e o educador nas mais variadas dimensões, entre elas a sensório-motora, cognitiva e simbólica, de forma que tais atores possam desenvolver compreensão crítica da realidade cultural em que estão inseridos.

Neste intuito, reforçamos em nossa metodologia um processo investigatório, onde a praxis acontece, respeitando as características de todos os envolvidos, assim como destacamos a priori uma sistematização baseada nos métodos de Boal (2009). Em outras palavras, elaboramos um procedimento padrão, consistente nas oficinas e entrevistas com participação ativa dos educandos, evidenciado por cronogramas, tabelas e demais registros pertinentes, que culminou na leitura dramática realizada pelo grupo, cujos resultados e considerações finais serão apresentados como último elemento. 


\section{OBJETIVOS}

\subsection{Geral}

Analisar o teatro como ferramenta pedagógica no desenvolvimento de habilidades, de talentos, de vocações, e autonomia dos alunos durante o processo de aprendizagem.

\subsection{Específico}

Observar o desenvolvimento das aulas no sentido de analisar ações mais maduras, mais positivas, mais seguras e prazerosas em seu aprendizado.

Verificar como ocorrem as interações sociais e artísticas dos alunos, tanto entre eles mesmos, assim com o profissional responsável sobre o projeto.

Analisar a interdisciplinaridade entre as artes visuais e as poéticas da cena.

Identificar quais experiências de leitura conduzem os alunos a desenvolverem o hábito da leitura e um novo olhar sobre o Patrimônio Material e Patrimônio Imaterial. 


\section{JUSTIFICATIVA}

Saber que pesquisas e estudos mostram e apontam para uma realidade difícil em termos de aprendizado, principalmente em artes cênicas, em educação patrimonial e também em relação ao estímulo a criatividade dentro de Instituições públicas ou particulares, não deveriam nos paralisar mas sim em nos instigar a ações concretas e práticas, como enxergar os alunos e alunas, segundo Maciel e Barbato (2015, p.61) “como seres pensantes e que seu desenvolvimento pode ocorrer como decorrência das trocas intersubjetivas, professor- aluno; aluno- aluno.”.

Os estudos de artes cênicas e artes visuais (incluir cultura visual) estão sofrendo modificações socialmente, mas ainda continuam sendo estigmatizados, como pertencentes a uma elite cultural, por isso urge entender que as práticas pedagógicas podem e possibilitam além de trocas pedagógicas, um desvincular de concepções cristalizadas que não respeitam a necessidade em repensar "a reconfiguração da própria função social do ser" segundo Maciel e Barbato (2015, p.45) seja como professor, e/ou aluno (a) em busca de uma maior autonomia tanto quanto ao aprender, como ao ensinar.

Precisamos nos ater que ensinar exige, segundo Freire (2011, p.36) "risco, a aceitação do novo e rejeição a qualquer forma de discriminação", e que o "pensar certo" (2011, p.37) tanto que, segundo ele, “A tarefa coerente do educador que pensa certo, é exercendo como ser humano a irrecusável prática de inteligir, desafiar o educando com quem se comunica, a quem comunica, a produzir sua compreensão do que vem sendo comunicado." (2011, p. 39).

Esta máxima nos move a experimentar a arte, (também nossa leitura dramatizada) pois ensinar "exige o reconhecimento e a assunção da identidade cultural" (FREIRE, 2011, p.39).

Para promover, divulgar e experimentar a máxima (citada acima) precisamos também instigar nosso (a)s aluno(a)s a vivenciar que "A cultura enfatiza as experiências diárias do visual e move, assim a atenção dada às Belas Artes, Artes Plásticas e Artes Visuais, ou seja, de uma cultura de elite para a visualização do cotidiano." (DIAS, 2007f, p. 7)

A escola hoje apresenta, infelizmente, um contexto onde ocorrem situações absurdas de violência em seus mais diversos aspectos, por isso, é fundamental estimular, promover, garantir e refletir que, segundo Maciel e Barbato (2015), "A sala de aula, 
presencial ou virtual, constitui cada vez mais, espaço de debate que organiza, com ativa participação dos alunos, informações e valores veiculados nos vários sistemas, produzindo conhecimento, cultura e subjetividade" (MACIEL; BARBATO, 2015, p. 48)

A sistematização de nosso trabalho e seu desenvolvimento, ressaltando a leitura dramática, parte dos princípios citados acima e foi elaborada também a partir dos métodos de Boal, principalmente em sua obra: "Jogos para atores e não atores", que propõe: "Os exercícios e jogos não devem ser feitos dentro do espírito de competição devemos tentar ser sempre melhores do que nós mesmos, e nunca melhor que os outros" (BOAL, 2009, p.10). E também através dos textos de Medeiros (2018) que nos estimula a dialogar e refletir sobre a Educação Patrimonial, ambiental e cultural.

De acordo com Belidson Dias (2017), “Artes Visuais é uma classificação que busca abarcar todas as possibilidades de construção da imagem em que o visual é priorizado e, de certa forma, até em detrimento de outros sentidos" (DIAS, 2007d, p. 5). Portanto, se explicita a junção das artes visuais com as artes cênicas, pois as artes visuais não estão em detrimento de nenhuma, pois as artes caminham sempre juntas e geram reflexões e possibilidades de "novas" aquisições, como a visão crítica do mundo e de nós mesmos.

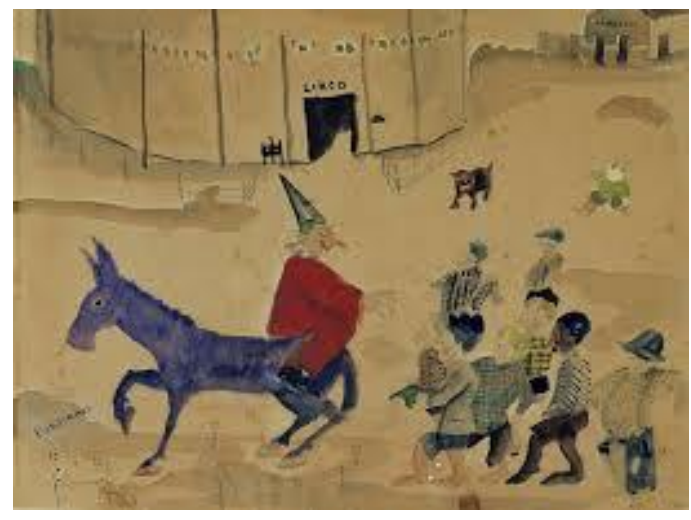

$\begin{array}{llllll}\text { Figura } 2: & \text { "Tendência } & \text { do }\end{array}$ https://tendimag.files.wordpress.com/2017/07/candido-portinari-circo-grande.jpg

A sociedade capitalista nos estimula e nos incentiva a nos tornarmos mercadoria e a deixarmos de acreditar na possibilidade de sonhar; somos o tempo todo estimulados a ter e a não ser. Por isso refletir, que a função permanente da arte é 
recriar para a experiência de cada indivíduo a plenitude daquilo que ele não é, isto é, a experiência da humanidade em geral. A magia da arte está em que, nesse processo de recriação, ela mostra a realidade como possível de ser transformada, dominada e tornada brinquedo (FISCHER, 2007, p.252).

A partir desses pensamentos e estímulos somos levados a acreditar não apenas na arte e em nosso projeto artístico, que respeitará todos as modificações sofridas ao longo de seu amadurecimento próprio - pois estamos lidando também com o lúdico e com nossa sensibilidade - e ao mesmo tempo com realidades opostas ao que almejamos, pois enfrentamos complexidades, não apenas em termos econômicos ou sociais (como a improvisação de espaços físicos nas escola para apresentações artísticas) mas também culturais, sociológicos e filosóficos.

Trazer a cena, a necessidade do resgate e entendimento a questões ligadas diretamente ao patrimônio material e imaterial, como as obra de Cândido Portinari, utilizada como inspiração para a criação de cenas, de figurinos, de cenografias e iluminação dentro da concepção artística de nosso trabalho artístico, e da obra de Graciliano Ramos ("Vidas Secas") para também desenvolver as poéticas da cena, é poder discutir nossa identidade, nossa cidadania e principalmente estratégias que apresentam, segundo Medeiros $(2018$, p.3) '(...) A educação patrimonial, ambiental e cultural como condição sine qua non para a prática preservacionista, na construção das identidades locais, nacionais, regionais e internacionais.”.

Sabemos que não é somente através da criatividade, que reforçamos: Todo educador deve "ajudar seus alunos a definir seus pensamentos limitadores, a reconhecer e comunicar seus medos e seus verdadeiro sentimentos e desejos. Pois o educador também é um agente atuante na formação de uma personalidade” (URRUTIGARAY, 2008e, p.39). A escola tem uma proposta ideológica e política por natureza, pois “ Além do ensino, a escola ajuda a formar traços do que se espera de um sujeito inserido em uma cultura específica”. (MACIEL; BARBATO, 2015, p.48).

Entender a importância da Interface entre as artes visuais e as poéticas da cena, como processo que serve como referência para o desenvolvimento de políticas educacionais e políticas públicas é relevante, pois visa também a implantação e a difusão de novas ações práticas, preocupadas não somente com o homem, mas também como o estímulo a novas linhas de pensamento.

Entretanto, é fundamental entender que apesar de alguns críticos reafirmarem que: (séries "Retirantes” Portinari, 1944) “A ligação das Séries com a temática dos livros 
de Graciliano Ramos é automática, reconhecida pelos próprios artistas" (BALBI; 2003, p.50) temos que ir além da afirmativa e refletir as próprias palavras de Graciliano Ramos, segundo Balbi (2003) quando nos questiona, de forma incisiva: (carta enviada ao pintor em fevereiro de 1946)

\footnotetext{
Dizem que somos pessimistas e exibimos deformações; contudo as deformações e a miséria existem fora da arte e são cultivadas pelos que nos censuram. $\mathrm{O}$ que às vezes pergunto a mim mesmo, com angústia Portinari, é isto: se elas desaparecessem, poderíamos continuar a trabalhar? Desejaremos realmente que elas desapareçam, ou seremos também uns exploradores, tão perversos como os outros, quando expomos desgraças? (BALBI; 2003, p. 51).
}

Diante dessas informações e reflexões importantes destacamos que é necessário e principalmente rico instigar aluno(a)s a repensarem o papel do artista, de suas obras, de suas ideologias e de suas posições políticas, assim como o papel da arte e da escola, pois o homem está cada vez mais afastado de si mesmo e do outro e que a família, a escola, o trabalho e a arte nos influenciam decisivamente em nossa formação moral, formação ética, formação intelectual, formação ideológica e principalmente em nossas formações profissionais e pessoais. 


\section{FUNDAMENTAÇÃO TEÓRICA}

O trabalho desenvolvido, por meio do trabalho realizado, levou os membros do grupo a: 1 - Estudar e ter condições de experimentar, assim como vivenciar a aplicação de jogos dramáticos, como teatrais (criados por Boal) e de exercícios de improvisação (livres e direcionados); 2 - Materialização de uma leitura dramática, através da junção do texto Vidas Secas e das obras de Cândido Portinari escolhidas pelos alunos e professor; 3 - Experimentar e vivenciar a diferenciação entre leitura branca e leitura dramatizada; 4 - Conhecer, rediscutir e experimentar exercícios de voz (também Boal); 5- Apresentar-se em público, através da leitura dramática (com duração de 60 minutos); 6 - Participar de estudos com abrangência em Patrimônio Material e Patrimônio Imaterial, assim como Ambiental e Cultural; 7 - Participar de exercícios coletivos e de análises de textos (individual e coletivo) ; 8 - Participar de filmagens do produto final ( com debate após as apresentações - 2 sessões - ); 9 - Discutir, avaliar e repensar a experiência artística.

Importante enfatizar que apesar do grupo reagir de forma positiva à proposta apresentada inicialmente, este apresenta dificuldades: 1 - maior facilidade nos jogos dramáticos (onde todos são jogadores) e dificuldades com os jogos teatrais (onde os participantes alternam papéis de jogadores e observadores). Isto explicita que o grupo altamente introspectivo, expunha-se com menos medo e receio, quando não era julgado e/ou observado pelo outro, mas quando estimulado a expor sua opinião (por mais extrovertido que possa ser o aluno ou aluna) e a encontrar saídas (solução cênica através das imagens escolhidas -obras de Portinari - ) este se retraia; 2 - O grupo se sente mais confiante quando as cenas são marcadas somente com a intervenção do professor, porém, reagi com maior cautela quando os exercícios são mais livres (p. ex.: quando foi sugerido o uso de roupas coloridas aos ensaios). É de fundamental importância relatar que os(as) alunos(as) se sentiram mais confiantes e aliviados quando foi sugerido que apenas algumas cenas (escolhidas pelo professor - após ouvir a opinião do grupo) seriam decoradas.

Em relação a utilização do texto em mãos, é necessário esclarecer que o projeto não tem como finalidade única a criação de personagens, ou de cenas, utilizando apenas o texto escrito (adaptado pelo professor) mas propõe a não dicotomia entre as imagens (obras de Portinari) e o texto de Graciliano Ramos, pois o teatro, não se limita a uma única concepção artística, ou a uma única técnica na criação de personagens. É imprescindível também esclarecer que as apresentações são realizadas sempre sem a 
quarta parede, ou seja, a separação entre atores e plateia, pois o espaço físico adaptado (sala de exibição de filmes e palestras) propõe esta junção e a participação ativa do público.

Conhecer as condições dos alunos e das alunas (levando em conta as experiências artísticas passadas com os mesmos e mesmas) se torna fundamental pela questão tempo de concretização do projeto (iniciado em Agosto) pois possibilita uma facilitação maior em todo processo de elaboração de cenas e de exigências quanto a questão das cenas mudas, ou seja, a não hegemonia da palavra. Um dos problemas enfrentados com maior rigor (não apenas no projeto já citado) é a grande dificuldade em ler (de forma correta e objetiva - com intenções nas falas) pois os (as) alunos(as) apesar de estimulados ao hábito da leitura (desde oficinas a partir de 2016) ainda demonstram alguma resistência, pois, na maioria das vezes, o hábito não é estimulado pelas famílias ou familiares.

A inclusão da plateia como não passiva (também proposta do projeto) não incomoda os participantes, por já terem experimentado (em anos anteriores) tal proposta. Entretanto existe ainda uma grande dificuldade em entender e explicitar na prática, as “intenções do autor", por isso, existe a preocupação de estimular e instigar sempre (nas aulas, para todas as séries) o exercício da compreensão do texto e de suas interpretações.

Não podemos deixar de salientar que o grupo compreende a necessidade das filmagens, não apenas como registro, mas também como um feedback necessário para a correção de erros. Urge esclarecer também que os(as) alunos(as) são sempre estimulados a participarem das entrevistas (mais livres, levando em conta suas ideias quanto a elaboração das mesmas) antes e após as apresentações, possibilitando assim reflexões e críticas sobre a experiência artística, levando em consideração os erros e acertos cometidos. 


\section{METODOLOGIA}

Compreender e considerar os objetivos propostos, é o ponto de partida para nossa metodologia que propõe como base o projeto Leitura Dramáticas, e o desenvolvimento de futuras etapas importantes e imprescindíveis para o resultado final.

No ano de 2016, eu recebi um convite, através de minha coordenadora no CEMART (Centro Municipal de Artes - Barretos- São Paulo) para poder desenvolver dentro da Escola Estadual Antônio Olympio uma oficina teatral, que deveria ter a duração de 1 ano. Desde de o primeiro encontro ficou estabelecido que a oficina poderia não ter continuidade, mas o convite foi estendido e até os dias atuais permaneço na Instituição citada, desenvolvendo atividades artísticas com os alunos do ensino médio, principalmente englobando os $8^{\circ} \mathrm{s}$ anos.

Após aceitar o convite ficou estabelecido que os encontros se dariam em dois dias da semana, (quartas e quintas feiras) e que as atividades seguiriam um horário diferenciado, ou seja, das $9 \mathrm{~h}$ as $12 \mathrm{~h}$ e em especial também as quartas feiras das $13 \mathrm{~h} 15$ até as $15 \mathrm{~h} 15$, apenas com os oitavos anos, ao qual realizo o projeto: Leitura dramáticas - sem a professora de português - ao qual desenvolvo outras atividades nos sextos anos e nos sétimos anos também.

Importante ressaltar que os alunos e alunas dos oitavos anos, aos quais realizam o projeto já haviam sido comtemplados com a oficina teatral desde 2016, e que desenvolvíamos (juntamente com a professora de português) atividades artísticas, como leituras dramáticas tendo como base os livros indicados pelo MEC, cujo conteúdo respeitamos, ou seja, textos de Maria Clara Machado, Sílvia Orthof, etc.

Por conhecer os alunos e alunas desde 2016, a escolha dos participantes (juntamente com a ajuda da professora de Língua Portuguesa) para o projeto já citado, foi muito segura e eficiente, sendo que os alunos e alunas mais dedicados e com maior grau de maturidade, levando em consideração suas posturas em salas de aula, sua dedicação e seu potencial artístico foram contemplados, sem problema algum, não causando, qualquer constrangimento ou revolta, aos alunos não contemplados, pois as leituras trabalhadas no o teatro com os alunos e alunas de outras séries estão ao todo vapor.

Diante disso, o projeto se iniciou a partir de Agosto de 2018 e propõe também uma transformação social e pessoal, assim como fazer com que o ser humano possa adquirir uma visão crítica sobre si mesmo e sobre o outro, levando ao desabrochar de 
potencialidades já existentes, mas ainda pouco descobertas, foi o que nos leva a elaborar a proposta de intervenção da pedagogia do teatro, pois esta atesta e da oportunidade ao grupo (composto pelos $8^{\circ} \mathrm{s}$ anos) de experimentar, entender e confirmar que:

Todo mundo atua, age, interpreta. Somos todos atores. Até mesmo os não
atores! Teatro é algo que existe dentro de cada ser humano, e pode ser praticado
na solidão de um elevador, em frente a um espelho, no Maracanã ou em praça
pública para milhares de pessoas. Em qualquer lugar. Até mesmo dentro dos
teatros (BOAL, 2009, p. 9).

Urge entender que o grupo trabalhado se propôs a vencer barreiras, medos e a buscar saídas para uma consciência de renovação (na prática) de valores pessoais, que na maioria das vezes, não são discutidos ou revelados aos pais, pois muitas vezes a falta de diálogo com os pais e amigos, leva o ser humano a além de se fechar dentro de si mesmo, a se ver como seres incapazes e "não produtivos". Por isso, é imprescindível refletir, discutir e questionar, durante os encontros, ensaios e em apresentações que precisamos deixar de lado nossas inibições, assim como deixar de participar deste processo de coisificação (ao qual vivemos) e de ter consciência de que é possível não se adequar a estereótipos, criados, estimulados pela sociedade capitalista e pelas famílias que não assumem a educação de seus filhos e filhas ( não frequentam as Instituições escolares e não participam do aprendizado de seus filhos e filhas).

Contudo, qualquer iniciativa a processos de mudança e de busca de autonomia exige rupturas e coragem (principalmente a uma geração que está cada vez mais dependente das ferramentas tecnológicas e cada vez mais individualizada) por isso, é fundamental perceber que " ensinar exige rigorosidade metódica.” (FREIRE, 2011, p.28) e de como, somos capazes em entender que temos direitos e deveres e que aprender é estimulante e prazeroso.

Trata-se, então de refletir que

ensinar e aprender têm que ver com o esforço metodicamente crítico do professor de desvelar a compreensão de algo e com o empenho igualmente crítico do aluno de ir entrando como sujeito da aprendizagem, no processo de desvelamento que o professor ou professora deve deflagrar (FREIRE, 2011, p. 108).

O desafio na concretização do projeto se dá, para o grupo assistido, assim como para o educador.

\section{ESPECIFICIDADES}

O trabalho desenvolvido levou em consideração o seguinte cronograma: 


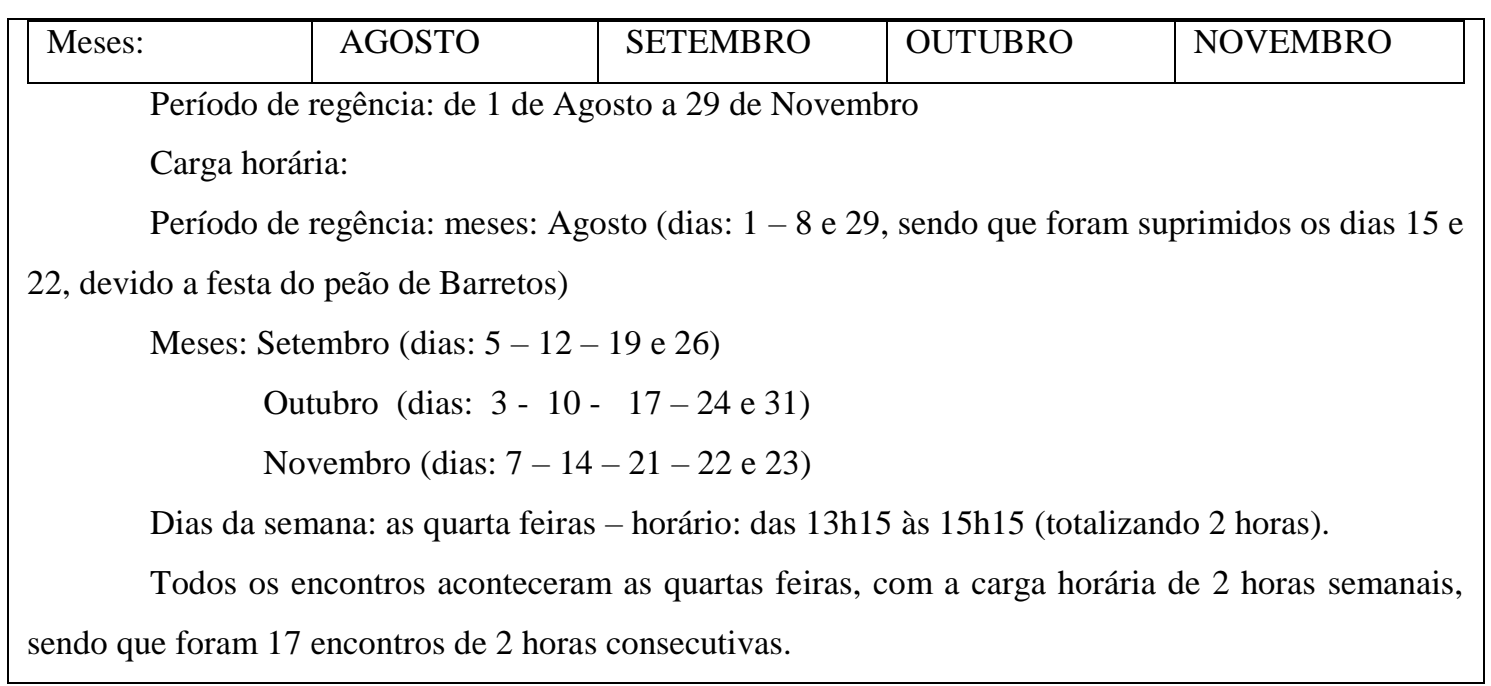

Observação: Desde o início do trabalho ficou esclarecido e especificado que não seriam permitidas faltas, não apenas pelo cumprimento do cronograma mas também pelo desenvolvimento artístico e pessoal de todos os envolvidos. Em função desta exigência, o grupo ficou reduzido a 12 participantes em cena (com 2 alunos - operando som e vídeo) totalizando 14 participantes. Os encontros foram iniciados e terminados em círculo, com aplicação de exercícios de voz e de corpo, passando a leitura de textos (VIDAS SECAS) e Patrimônio Material e Imaterial) visando a diferença entre leitura branca e dramática.

\section{SEQUÊNCIA DE JOGOS (proposta)}

\begin{tabular}{|l|}
\hline Mês de Agosto \\
Dia: 1 de Agosto $-1^{\circ}$ encontro - apresentação do texto (VIDAS SECAS) e \\
discussão sobre a proposta do projeto. Leitura do texto - sem discussão. \\
Dia: 8 de Agosto - leitura do texto, com discussão e proposta de jogos: "jogo de \\
ritmo e movimento" \\
Dia: 29 de Agosto - Começamos a examinar e conhecer algumas obras de \\
Portinari (levei alguns livros de pintura) e discutimos sobre como adaptar as imagens para \\
a cena. \\
\hline COMENTÁRIOS ABAIXO
\end{tabular}

O grupo apresentou interesse pelo projeto e pela possibilidade de participarem de forma mais ativa, causando inicialmente receio, pois ficaram preocupados com a necessidade de "levarem" tarefas para casa. Os estudantes ainda apresentam dificuldades em ler (fora da escola) mas já acontecem exceções, pois eles e elas já são estimulados a prática da leitura desde 2016. 
As dificuldades aconteceram quanto aos jogos (jogo de ritmo e movimento) pois demonstraram alguma lentidão em algumas ações, como por exemplo, a diferença entre acelerar e respeitar o ritmo da ação proposta. Entretanto, houve com o desenvolvimento dos jogos um amadurecimento em relação a percepção do conhecimento do próprio corpo. Percebe-se que somos instigados a dar uma menor importância a ações físicas em contraponto as ações verbais.

Importante destacar que no dia 29 o grupo apresentou maior dificuldade em retornar ao trabalho, pois as interrupções (devido a festa do peão) sofridas pelos dias 15 e 22 de Ag possibilitaram uma mudança no ritmo do grupo, propriamente dito. Houve a necessidade de retornar alguns pontos, como: a contradição entre fala e corpo. A partir desse ponto passamos a olhar algumas obras de Portinari (apenas introdução) e focar nas imagens (aleatórias). Apenas uma aluna e um aluno conheciam as obras de Portinari, mas todos o conheciam como "grande artista" (disseram).

\begin{tabular}{|l|}
\hline Mês de Setembro \\
personagens \\
\hline Dia: 5 de Setembro - Leitura do texto (com distribuição de papéis e discussão sobre os \\
imagens foram selecionadas pelos alunos. Iniciamos os jogos: "Anda, pára, justifica" \\
Dia: 19 de Setembro - Termino do jogo: " Anda, para, justifica". Início da marcação e leitura \\
do "coro de Gracilianos" Iniciação do jogo: "A orquestra e o regente". \\
Dia: 26 de Setembro - Marcação de cenas tendo como referências alguma obras de Portinari \\
(selecionadas pelos alunos e alunas) \\
COMENTÁRIOS ABAIXO
\end{tabular}

Os trabalhos começaram com reflexões tais como: $\mathrm{O}$ que nos faz acreditar na importância de um artista? Será que devemos nos satisfazermos apenas com as informações da mídia sobre determinados artistas ou escritores? Será que nosso país respeita as nossas memórias? E você, respeite-as? De que forma? Qual a importância da memória para o país e para a sua cultura? Como as imagens escolhidas nos chamam ou nos chamaram à atenção? Será que as imagens possuem movimento e nos emocionam? Comente. O que nos impressionou nas imagens da obra "Retirantes" (1944) ? As perguntas tiveram a intenção de fazê-los refletir, e buscar juntamente com os mesmos as respostas, pois não existe a necessidade em induzi-los a respostas prontas ou a reprodução 
das opiniões já conhecidas ou à respostas dos outros. Provocar e instigar são palavraschave.

Importante perceber que as nossas percepções, como a percepção seletiva, segundo Sérvio, é

[...] construída de maneira tácita, a partir de rotinas, de preferências e de práticas de olhar que se estruturam e ganham organicidade interna sem que nos demos conta. Ela se desenvolve de maneiras inconscientes, influenciadas por práticas culturais, por estímulos externos e /ou internos sobre os quais não temos consciência (SÉRVIO, 2014, p. 199).

Devemos como arte educadores e como artistas repensarmos nossas afirmativas e buscar juntamente com alunos e alunas reflexões e não respostas prontas ou não instigantes. Os jogos "Anda, para, justifica" apresentou dificuldades iniciais, principalmente com os meninos, pois as ações físicas foram realizadas aleatoriamente, ou seja, sem consciência corporal. Importante ressaltar que os jogos são uma prévia para que possamos observas as obras de Portinari em "ação" ou seja: as imagens possuem movimento e objetivos, mesmo estando estáticas, ou seja, devemos refletir as ações das imagens, tanto externas, como internas. São exercícios de maior complexidade, mas de suma importância para o trabalho artístico.

O jogo foi repensado e proposto novamente no próximo encontro (suas descobertas não se esgotam, mas possibilitam sempre novas descobertas). O jogo "A orquestra e o regente" também oferece complexidade, pois: "Cada um deve ter sua vez como regente e, com o mesmo material sonoro, organizar a sua própria música”. (BOAL, 2019, p.137). Os alunos e alunas são instigados a assumirem novos papéis e a justificarem suas ações, por isso, existe uma preocupação em desenvolver a UNIDADE do grupo, ou seja, trabalhar as ações coletivas e o sentido grupal e não individual.

Existe dificuldade nesta proposta, pois os alunos ainda permanecem em seus mundos particulares, pois quando são dispensados para beberem água ou irem ao banheiro, recorrem a seus celulares ignorando os colegas do grupo. A questão da utilização do celular foi discutida em sala de aula - levando em consideração a presença ou ausência deste durante apresentações culturais, musicais, entre outros - e solicitou-se desligá-lo durante a aula. Apenas uma aluna não concordou com a solicitação (justificando a necessidade da mãe em manter contato com ela) mas, a regra foi aceita posteriormente, com menor resistência. 
Falar sobre a criação de personagens, levando em consideração o pouco tempo disponível não é tão simples, por isso foi trabalhado principalmente as intenções dos personagens, pois o projeto não privilegia a construção dos personagens, propriamente dito, sendo que somente em algumas cenas exigiu-se a memorização de falas. As intenções e objetivos foram discutidos e experimentados, com dificuldades iniciais, mesmo tendo os estudantes experiência em teatro, dentro da escola, desde 2016.

Importante ressaltar que a leitura dramática respeita a forma "épica" de teatro, pois estamos trabalhando também com Graciliano Ramos - que propõe reflexões sociais em políticas nas ações de seus personagens -, sendo que a forma épica vê o homem como “alterável, objeto de estudo, está “em processo" (BOAL, 1983, p.115) e não como sendo o homem fixo, inalterável e considerado como conhecido, como a forma dramática. A leitura dramática não propõe a catarse - que no final purifica o espectador - mas sim estimular o espectador a reflexão, através “ do conhecimento, o espectador é estimulado à ação" (BOAL, 1983, p.115).

As marcações de cena respeitam as necessidades, as dificuldades, os limites, os acertos e o potencial dos estudantes, pois não estamos trabalhando com profissionais não é o objetivo - mas sim com alunos e alunas pensantes, sensíveis e altamente capacitados a repensarem as obras trabalhadas, como possibilidade de crescimento pessoal e artístico. Como nos diz Martins e Tourinho, precisamos possibilitar que os estudantes "encontrem seu lugar para aprender com sentido e construir experiências de saber que lhes permitam não somente interpretar o mundo, mas também atuar sobre ele". Propomos uma interação entre as imagens escolhidas (ainda em processo) e as intenções do autor. Importante registrar: Como as imagens nos chamam à atenção? Será que as imagens possuem movimentos e nos emocionam? Comente. O que mais nos impressiona nas imagens da obra "Retirantes" (1944)?

\begin{tabular}{|l|}
\hline Mês de Outubro \\
Dia: 3 de Outubro - Marcações de cena com discussões sobre o trabalho corporal dos alunos e \\
das alunas. \\
\hline Dia: 10 de Outubro - Introdução sobre a educação patrimonial - Texto: "Educar, participar e \\
preservar"
\end{tabular}


Dia: 17 de Outubro - Rediscutir a questão da preservação - Levar em consideração as vivências pessoais dentro e fora da escola.

Dia: 24 de Outubro - Marcação com microfones e discussão sobre as relações entre os personagens e suas visões de mundo - Introdução a ideologia política de Graciliano Ramos e Candido Portinari.

Dia: 31 de Outubro - Discutir questões: Visão e Visualidade e Ensaio de cenas. Texto: Pesquisa \& Práticas de Pesquisas em Cultura Visual \& Educação. Iniciar reflexões sobre a Constituição de 1988, através dos artigos 215 e 216. Texto: PATRIMÔNIO CULTURAL: CONSCIÊNCIA E PRESERVAÇÃO. - Sandra C. A. Pelegrini.

Obs: A leitura do texto foi realizada em todos os encontros.

COMENTÁRIOS ABAIXO

Os alunos e as alunas por estarem mais familiarizados com o texto não apresentam tantas dificuldades quanto a questão da leitura (sendo que $90 \%$ dos alunos não leem em casa) sendo que houve muita dificuldade inicial principalmente por parte dos meninos.

As marcações seguiram as sugestões do autor, ou seja, suas intenções, o que causou espanto e surpresa ao grupo, pois ele apresentava dificuldade em interpretar o texto (enquanto literatura). O sentido das palavras e seus significados foram discutidos, assim como se iniciou a discussão sobre o patrimônio imaterial. Algumas reflexões foram lançadas: Quais as falas que apresentam relação com o patrimônio imaterial? Nos reconhecemos nos exemplos citados pelo autor? Pois não podemos deixar de nos lembrar que segundo Medeiros, precisamos

\footnotetext{
preservar para educar, ou seja: a concepção em si dos bens históricos e artísticos nacionais como uma herança que se passa de geração a geração de modo que o futuro conheça, entenda o passado, a memória, a história, já demonstra o desejo de instruir, no presente, o hoje jovem, sobre o ontem, de modo a possibilitar a construção mais segura, pelo adulto, do amanhã. (MEDEIROS, 2018, p. 4).
}

Falar em vivências dentro e fora da escola ainda é necessário e importante pois a maioria dos educadores não estabelecem uma relação dialógica com seus alunos e alunas, o que é fundamental, principalmente nas séries do ensino fundamental, propriamente dita. A educação deveria abordar a leitura e a escrita como processos psicológicos, e não como uma obrigatoriedade apenas, pois segundo Maciel e Barbato,

Partindo da nossa experiência de ler, pode-se dizer que, embora nós percebamos a leitura de uma palavra como algo que fazemos de uma só vez, essa envolve, na verdade, várias habilidades interrelacionadas e que ocorrem simultaneamente em vários níveis. Isto é, transformamos a informação visual 
gráfica (os grafemas ou símbolos escritos) em significado. (MACIEL E BARBATO, 2015, p. 113).

Isso requer, um conhecimento sério e com capacitação para podermos então promover um aprendizado adequado e eficiente que promoverá processos de informações adequados e seguros.

A partir do amadurecimento do grupo trabalhado, passamos a discutir o que seria a chamada cultura visual e visualidade. Para Martins e Tourinho (2013) devemos pensar a cultura visual como uma "metodologia viva", pois sabemos que, segundo eles, devemos considerar os estudos da cultura visual em

Contínua transformação, na medida em que novas situações políticas, dilemas éticos, documentos históricos, viradas conceituais e novos objetos, artefatos e mídias, assim como ambientes de cultura visual e perguntas colocadas pela cultura visual, afetam nosso modo de visão (visualidade). (MARTINS E TOURINHO, 2013, p. 78).

A escola é ou deveria ser um ambiente de descobertas e deveria proporcionar não somente o reconhecimento do mundo, mas também o de nós mesmos, por isso, a dificuldade em levar alunos e alunas a tomarem atitudes ativas em seu aprendizado.

Considerando que o nosso trabalho propõe um trabalho coletivo, estimulamos e instigamos nossos alunos e alunas a refletirem: Como as personagens enfrentam a solidão? Como o autor retrata a questão do conhecimento no texto? E quanto a questão da visualidade salientamos, que a cultura visual na educação deveria repensar, segundo Martins e Tourinho que " o que é relevante da pedagogia da cultura visual não são os objetos, mas sim as relações que mantemos com eles" (MARTINS E TOURINHO, 2013, p. 83).

Nossos questionamentos e reflexões com os (as) alunos(as) não estão restritos a obra de Graciliano Ramos, mas com o universo de sua obra, que vai além do texto escolhido, por isso sugerimos: Qual a relação que as personagens mantem com seus objetos? Essas relações existem? Cite-as.

As atividades propostas - as perguntas - não ficaram restritas à sala de aula, pois estamos lidando com o fator tempo, ou seja, algumas perguntas foram realizadas com o intuito dos alunos as reconhecerem como tarefas de casa. Entretanto, houve uma dificuldade inicial - superada durante o processo de trabalho - para que tal proposta fosse aceita e realizada prontamente. 
Hoje, os alunos e alunas se utilizam das ferramentas tecnológicas, para poderem assumir uma atitude mais passiva em relação ao seu aprendizado ou as suas pesquisas, por isso, se torna importante aliar as ferramentas tecnológicas às aulas e proporcionar grandes achados e descobertas, pois o mundo está em movimento constante e cada vez mais globalizado e as altas tecnologias oferecem oportunidades excepcionais, como por exemplo a realidade em E.A.D. (Educação à Distância). Atestamos que precisamos repensar nosso modo de ensinar e nossa relação com as altas tecnologias, que nos faz romper com barreiras territoriais e nos proporciona também uma maior democratização no ensino.

Já em relação com as reflexões sobre os artigos 215 e 216 da Constituição de 1988, ressaltamos que foi iniciada uma primeira abordagem e foi solicitada aos alunos e alunas indagações sobre o tema como por exemplo: Como podemos contribuir para que o Estado cumpra com os seus deveres? E como devemos cuidar de nossos direitos e deveres também? Você já conhecia ou somente ouvir falar na Constituição de 1988 ?

Para encerrar, destacamos que,

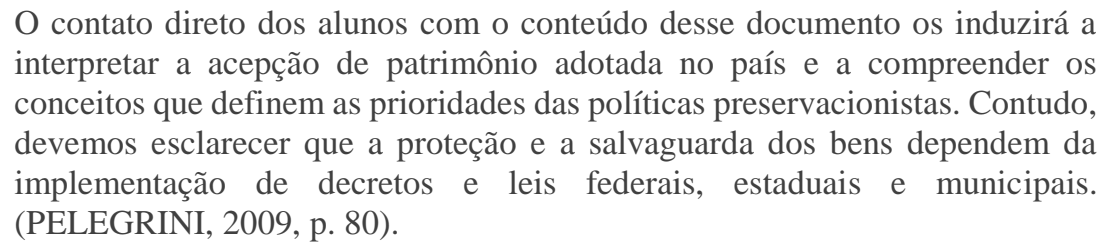

Esse trabalho de reflexão, propriamente dito, levou também os (as) alunos(as) a entenderem, segundo Pelegrini, que:

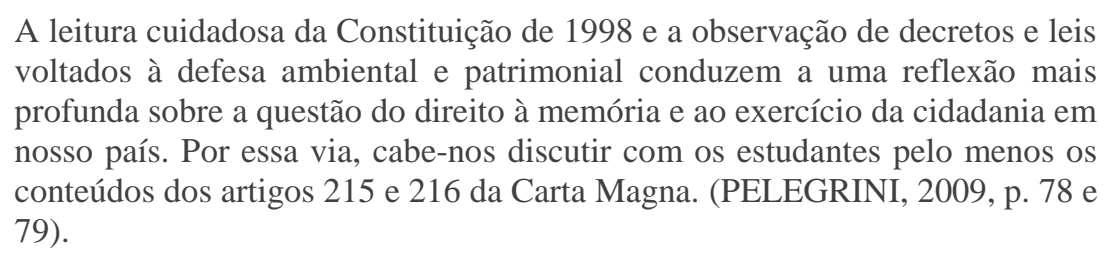

Nesse sentido, disponibilizamos (abaixo) o texto gerador que introduz os artigos 215 e 216 da Carta Magna.

TEXTO GERADOR: CONSTITUIÇÃO FEDERAL DE 1988.

Título VIII - Da ordem Social, Capítulo III - Da educação, da cultura e do desporto - artigos 215 e 216. 
Art. 215. O Estado garantirá a todos o pleno exercício dos direitos culturais e acesso às fontes da cultura nacional e apoiará e incentivará a valorização e a difusão das manifestações culturais.

$\S 1^{\circ}$ O Estado protegerá as manifestações das culturas populares, indígenas e afro-brasileiras, e das de outros grupos participantes do processo civilizatório nacional.

$\S 2^{\circ}$ A Lei disporá sobre a fixação de datas comemorativas de alta significação para os diferentes segmentos étnicos nacionais.

Art. 216. Constituem patrimônio cultural brasileiro os bens de natureza material e imaterial, tomados, individualmente ou em conjunto, portadores de referência à identidade, à ação, à memória dos diferentes grupos formadores da sociedade brasileira, nos quais se incluem:

I - as formas de expressão;

II - os modos de criar, fazer e viver;

III - as criações científicas, artísticas e tecnológicas;

IV - as obras, os objetos, os documentos, as edificações e os demais espaços destinados às manifestações artístico- culturais;

V - os conjuntos urbanos e sítios de valor histórico, paisagístico, artístico, arqueológico, paleontológico, ecológico e científico.

$\S 1^{\circ}$ O poder público, com a colaboração da comunidade, promoverá e protegerá o patrimônio cultural brasileiro, por meio de inventários, registros, vigilância, tombamento e desapropriação, e de outras formas de acautelamento e preservação.

$\S 2^{\circ}$ Cabem à administração pública, na forma da lei, a gestão da documentação governamental e as providências para franquear sua consulta a quantos dela necessitem.

$\S 3^{\circ} \mathrm{A}$ lei estabelecerá incentivos para a produção e o conhecimento de bens e valores culturais.

$\S 4^{\circ}$ Os danos e as ameaças ao patrimônio cultural serão punidos, na forma da lei. 
$\S 5^{\circ}$ Ficam tombados todos os documentos e os sítios detentores de reminiscências históricas dos antigos quilombos.

\section{TEXTO GERADOR: CONSTITUIÇÃO FEDERAL DE 1988.}

Título VIII - Da ordem Social, Capítulo III - Da educação, da cultura e do desporto - artigos 215 e 216.

Art. 215. O Estado garantirá a todos o pleno exercício dos direitos culturais e acesso às fontes da cultura nacional e apoiará e incentivará a valorização e a difusão das manifestações culturais.

$\S 1^{\circ} \mathrm{O}$ Estado protegerá as manifestações das culturas populares, indígenas e afro-brasileiras, e das de outros grupos participantes do processo civilizatório nacional.

$\S 2^{\circ}$ A Lei disporá sobre a fixação de datas comemorativas de alta significação para os diferentes segmentos étnicos nacionais.

Art. 216. Constituem patrimônio cultural brasileiro os bens de natureza material e imaterial, tomados, individualmente ou em conjunto, portadores de referência à identidade, à ação, à memória dos diferentes grupos formadores da sociedade brasileira, nos quais se incluem:

I - as formas de expressão;

II - os modos de criar, fazer e viver;

III - as criações científicas, artísticas e tecnológicas;

IV - as obras, os objetos, os documentos, as edificações e os demais espaços destinados às manifestações artístico- culturais;

V - os conjuntos urbanos e sítios de valor histórico, paisagístico, artístico, arqueológico, paleontológico, ecológico e científico.

$\S 1^{\circ}$ O poder público, com a colaboração da comunidade, promoverá e protegerá o patrimônio cultural brasileiro, por meio de inventários, registros, vigilância, tombamento e desapropriação, e de outras formas de acautelamento e preservação.

$\S 2^{\circ}$ Cabem à administração pública, na forma da lei, a gestão da documentação governamental e as providências para franquear sua consulta a quantos dela necessitem. 
$\S 3^{\circ} \mathrm{A}$ lei estabelecerá incentivos para a produção e o conhecimento de bens e valores culturais.

$\S 4^{\circ}$ Os danos e as ameaças ao patrimônio cultural serão punidos, na forma da lei.

$\S 5^{\circ}$ Ficam tombados todos os documentos e os sítios detentores de reminiscências históricas dos antigos quilombos.

Importante registrar que a sistematização do trabalho só é possível e respeitada se os(as) aluno(as) assumirem suas funções com responsabilidades, é essa premissa acontece sem problemas, pois $90 \%$ dos(das) alunos(as) já tiveram experiência anteriores, dentro da Instituição (já citada).

Não podemos deixar de creditar que através dos livros de Augusto Boal "Jogos para atores e não atores" e "O teatro do oprimido e outras poéticas políticas" este autor nos deu condição de (além de refletir essas questões) entender e aplicar toda uma sistematização de uma técnica que nos impulsionaram a trabalhar a "interface entre as artes visuais e as poética das cenas.”, pois como ele mesmo reafirma, podemos encontrar - através de uma metodologia clara e desafiadora - uma condição interna de mudanças, passando de passivos a ativos de nossa reconstrução pessoal e que o teatro propõe esta mudança.

Para, entretanto poder entender e atuar juntamente com os(as) alunos(as) no projeto foi indispensável o máximo de conhecimento sobre as obras de Portinari e um conhecimento claro sobe Patrimônio Material e Imaterial, pois estamos lidando com Graciliano Ramos e Cândido Portinari, por isso, não podemos ignora a contribuição de "Educação Patrimonial, ambiental e Cultural", onde encontramos material altamente qualificado e inspirador.

É mister neste momento salientar que o grupo assistido e trabalhado, sentiu-se recompensado e estimulado a participar das 2 apresentações propostas, sendo que se propôs a dar continuidade ao trabalho, pois reconhece a sua importância para o seu processo de maturidade e de maturação, tendo como intenção ainda a formação do $1^{\circ}$ grupo de teatro da Instituição, da cidade de Barretos. A vontade já existia a partir de 2017, 
mas agora se concretizou com maior rigor, sendo que existe o total apoio da direção e coordenação pedagógica da Instituição (já citada).

O desenvolvimento do trabalho prima também pela consciência da ações atos, ou seja, a leitura através de jogos dramáticos e Teatrais (já citados) tem a premissa de que: “Os exercícios e jogos não devem ser feitos dentro do espírito de competição - devemos tentar ser sempre melhor do que nós mesmos, e nunca melhor que os outros" (BOAL, 2009, p. 10)

A importância em reconhecer tal premissa e a estimular o pensamento coletivo e colaborativo levam alguns e algumas participantes a mudanças significativas em seu cotidiano, pois estes passaram a dialogar e sair de seu mundo protegido e fechado (altamente introspectivo) levando-os a também realizarem um trabalho com a professora de português com maior iniciativa (maior participação em aulas com textos do MEC) e redescobrir o prazer da leitura.

A iniciativa de uma leitura dramática foi a resposta necessária ao grupo, por não ser a primeira experiência artística realizada na Instituição (já mencionada) a leitura dramática então redescobre o prazer do contato com o público, com a arte e com nossa própria "voz" pois vezes ignoradas ou desconhecidas pelos(as) alunos(as).

Uma das maiores dificuldades, porém, está ainda na busca por uma autonomia (não estimulada ou negada no ambiente familiar), ou seja, a concretização de mudanças significativas em suas vidas (também fora da escola). Por isso, foi fundamental leva-los a refletir e repensar que:

\footnotetext{
Pessoas assim fazem parte das legiões de ofendidos que não percebem a razão de sua dor na perversidade do sistema social, econômico e político e que vivem, mas na sua incompetência. Enquanto sentirem assim, pensarem assim e agirem assim, reforçam o poder do sistema. Se tornam coniventes da ordem desumanizante (FREIRE, 2011, p. 81)
}

Assim, Freire (2011) considera que ninguém é sujeito da autonomia de ninguém e nos faz repensar que "a autonomia, enquanto amadurecimento do ser para si, é processo, é vir a ser.”(FREIRE, 2011, p.105) Por isso, torna-se importante reafirmar que é preciso uma grande atenção as series do ensino fundamental, pois a valorização destas desencadeiam uma maior e mais qualitativa interação entre alunos- alunos, como entre alunos- professores e que essa interação irá influenciar decididamente - de forma positiva - as carreiras no ensino médio e no ensino superior. 
Decorrente da argumentação anterior, existiu a necessidade em criarmos entrevistas (2) duas, (de forma menos rígida, não tão estruturadas) com roteiros não inibidores ou incisivos, pois elas foram elaboradas a partir dos objetivos da pesquisa, sendo que além deste instrumento, utilizamos também, como coleta de dados, uma observação livre de abordagem qualitativa, visando à compreensão da realidade dos sujeitos que participaram deste projeto.

\begin{tabular}{|c|}
\hline \multicolumn{1}{|c|}{ Mês de Novembro } \\
trabalhos sobre o mural de Portinari. \\
\hline Dia: 7 de Novembro - Término das discussões sobre os artigos 215 e 216 e iniciação aos \\
\hline Dia: 21 de Novembro - Ensaio - finalização de marcações \\
\hline Dia: 22 de Novembro - Ensaio geral \\
Dia: 23 de Novembro (específico) \\
Haverá duas sessões de "Vidas Secas", sendo respectivamente as: $10 \mathrm{~h}$ (com debate) e as $12 \mathrm{~h}$ \\
(sem debate).
\end{tabular}

A questão da continuidade das discussões e reflexões sobre os artigos (já citados) se deu em função de estarmos atentos as nossas ações práticas, ou seja, para podermos respeitar nossos direitos e deveres como cidadãos, precisamos estar informados sobre o assunto, repensar e rediscutir posições ideológicas, que muitas vezes ignoramos ou desconhecemos.

Se torna importante trabalhar também com os(as) alunos(as) o mural de Portinari, por isso escolhemos, como exemplo: o mural do Palácio Gustavo Capanema (Rio de Janeiro) cuja dimensão é de 280 x $300 \mathrm{~cm}$ (cada um). Não podemos deixar de destacar que, segundo Pelegrini (2009)

Esse artista plástico foi convidado pelo governo Vargas para confeccionar
vários murais para prédios públicos. Entre 1936 e 1938, o edifício que abrigava
o Ministério da Educação e Saúde, sob o comando de Gustavo Capanema, foi
brindado com uma obra cujo tema se ocupou dos ciclos econômicos do Brasil.
Cada um dos murais da coleção do Palácio Gustavo Capanema possui
dimensões que variam em torno de 280 x 300 cm.(PELEGRINI, 2009, p. 92)

Agora vamos as informações sobre o mural (descrito acima) e em função disso elaboramos a seguinte atividade: o material será mostrado ao aluno - através de livros - 
e em seguida iremos trabalhar com eles(elas) as seguintes informações, segundo Pelegrini (2009).

Atividade: Mural - Evidenciar a figura dos trabalhadores e a exploração de negros e indígenas.

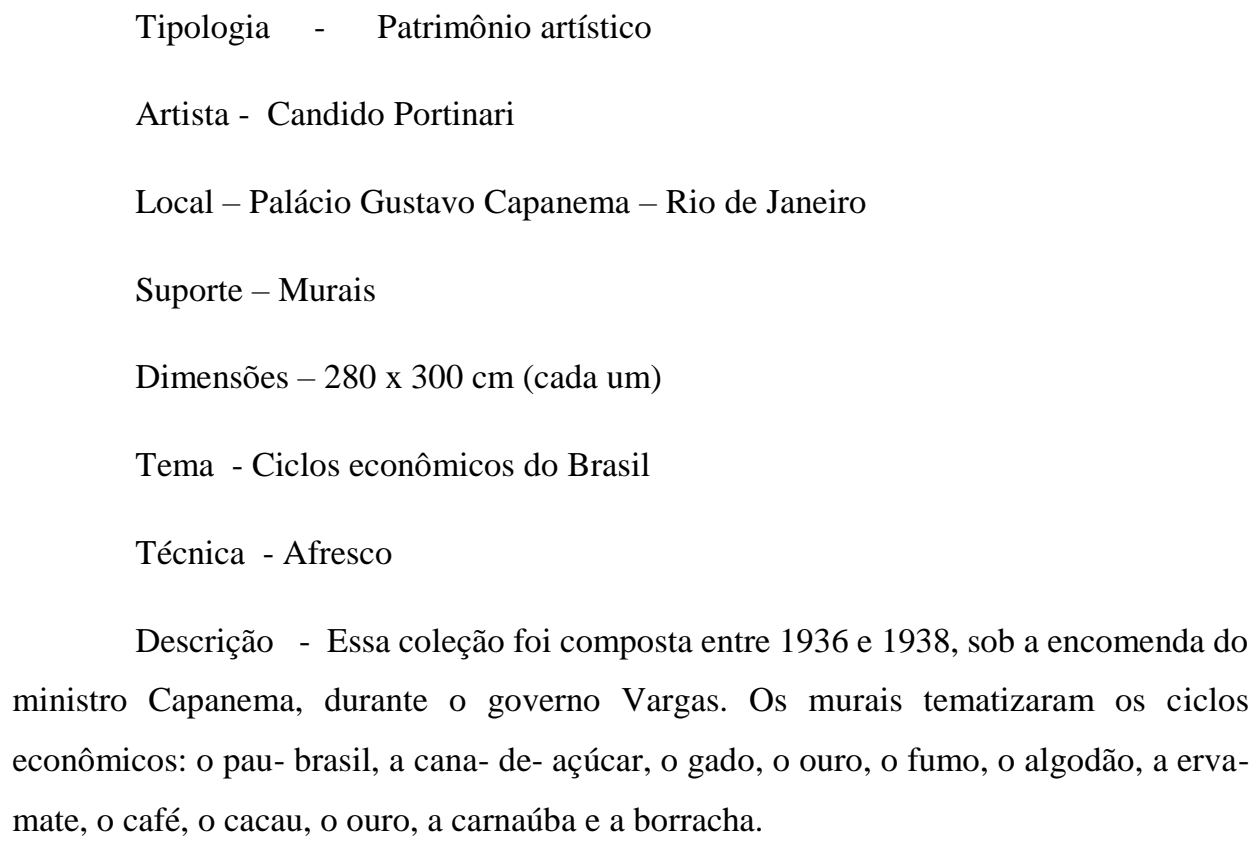
econômicos: o pau- brasil, a cana- de- açúcar, o gado, o ouro, o fumo, o algodão, a ervamate, o café, o cacau, o ouro, a carnaúba e a borracha.

Palavras- chave - Obra de arte, monumento, bens materiais, patrimônio artístico.

Objetivo geral da aula - Aprofundar a temática do patrimônio histórico, articulado à arte e à memória social.

Salientar as articulações entre a cultura material e a sociedade.

Destacar a relação entre os ciclos econômicos e a exploração do trabalho dos indígenas e negros. ${ }^{3}$

As propostas que envolveram o mural de Portinari objetivavam levar alunos e alunas a terem uma abordagem dos temas sociais que, segundo Pelegrini (2009) ...”estavam presentes nessa

3 PELEGRINI, Sandra C.A. Patrimonio Cultural: consciência e preservação. São Paulo, Brasiliense, 2009; p.92 e 93. 
fase da obra de Portinari, por essa razão, e embora os murais tematizassem os ciclos econômicos, evidenciavam a figura dos trabalhadores e a exploração de negros e indígenas." (PELEGRINI, 2009, p. 92).

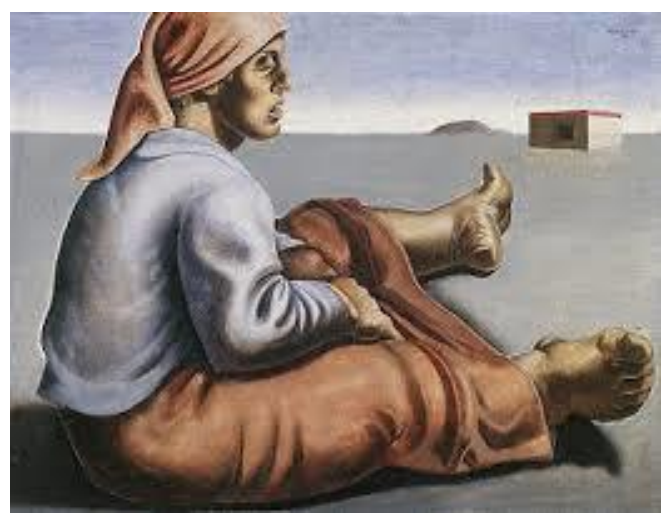

Figura 3: "Cabocla sentada" - Fonte: http://www.base7.com.br/portfolio/ver/127

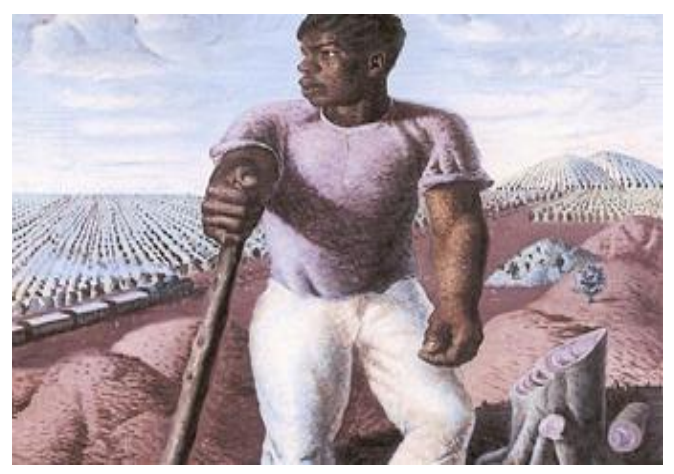

Figura 4: "Lavrador de Café" - Fonte: ROSA, Nereide S. S. Cândido Portinari, p. 15.

Importante ressaltar que na obra "Vidas Secas", a figura de Fabiano é contrastada a figura do negro e também aos "judeus errantes", pois existe a necessidade de rediscutirmos questões importantes (também) como a mão de obra escrava, a exploração do branco, e as aspirações por mudanças de vida. Em função disso escolhemos, juntamente com alunos (alunas) figuras significativas (obras de Portinari) para comporem o mural cenográfico da cena, não como simples ilustração, mas como metalinguagem. 


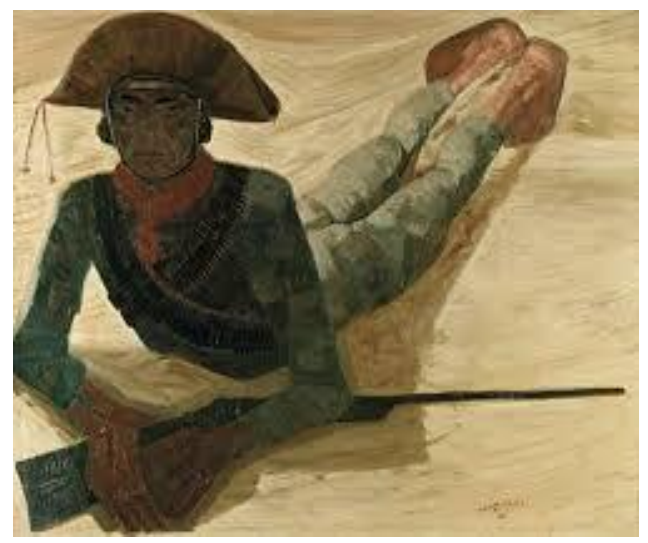

Figura 5: "Cangaceiro" - Fonte: ROSA, Nereide S. S. Cândido Portinari, p. 24.

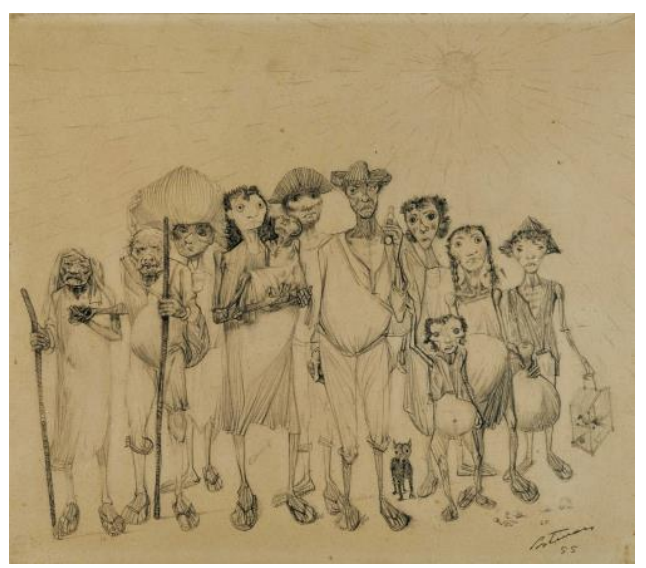

Figura 6: "Retirantes" - Fonte: http://www.elfikurten.com.br/2011/02/candido-portinari-mestres-dapintura.html

Os ensaios ocorreram sem graves problemas, pois o erro, é um elemento favorável para a construção de cenas ou das personagens. E as apresentações aconteceram de forma madura e responsável, sendo que houve surpresas positivas por parte do público (expostas pelos professores e pais presentes - sendo 3 pais ao todo) pela maturidade artística do grupo de alunos, devido principalmente pela complexidade do tema e da concepção artística. A segunda sessão apresentou problemas técnicos, mas que foram vencidos pelo preparo técnico dos (as) alunos(as)e pelo senso de responsabilidade dos participantes.

O caráter ativo de alunos(as) fizeram com que o debate fosse realizado com seriedade e responsabilidade, pois a coordenação do projeto instigou alunos(as) a responderem a maioria das perguntas, sem interferência direta. 


\subsection{Procedimento de Observação}

Não podemos deixar de esclarecer também que abordamos os sujeitos, durante a entrevista, esclarecendo os objetivos da pesquisa e propondo sugestões relevantes para o trabalho, assim como apresentamos uma carta de intenção (Anexo B) para formalizarmos sua aceitação.

As entrevistas foram realizadas no local das aulas (em dias diferentes) mediante o consentimento do grupo assistido, e tiveram a duração de uma hora. Destacamos ainda que houve a intenção de resguardar o sigilo dos(as) alunos(as) e que houve uma plena aceitação quanto a sugestão por parte deles na elaboração das perguntas, pois se sentiram acolhidos e mais ativos neste processo de investigação.

Para terminar, reforçamos que foram utilizados questionários - cujas informações serão apresentadas através de gráficos, ou tabelas - e também que as falas dos alunos serão descritas estatisticamente, organizadas e apresentadas posteriormente.

\subsection{Procedimento de análise de dados}

Os dados foram analisados, DESLANDES (2010) onde seguimos a: Identificação e problematização das ideias explicitas e implícitas; Busca dos sentidos mais amplos (sócio culturais); Diálogos entre as ideias problematizadas; Informações preeminentes de outros estudos e o referencial técnico do estudo.

Primeira etapa: Após a leitura do material (as entrevistas realizadas em diversos encontros) identificamos os temas escolhidos (mês de Setembro): A importância de um artista e de como sua obra é veiculada pelos veículos de comunicação de massa; A questão da memória e de sua relação com a sociedade e cultura; A importância das imagens e em especial as da selecionadas para a leitura dramática; As impressões da imagem "Retirantes" de Candido Portinari e a possibilidade em perceber as "imagens em movimento" e suas "emoções".

Segunda etapa: Recortamos trechos de depoimentos e nele identificamos ideias explícitas e implícitas. 
Estrutura de análises: Em busca de uma maior compreensão e organização, utilizaremos a divisão em dois grupos (grupo $\mathrm{A}$ - meninos -5 integrantes e grupo B meninas -7 integrantes) ressaltando que a estrutura partiu de: $\mathrm{O}$ teatro como leitura dramática e estudos sobre o Patrimônio Material e o Patrimônio Imaterial.

Obs: Utilizaremos pseudônimos.

\begin{tabular}{|c|c|c|c|c|}
\hline Depoimentos & MENINOS & MENINAS & IDEIAS & \\
\hline $\begin{array}{l}\text { "Eu me preocupo } \\
\text { com as memórias } \\
\text { do País." Gabriela }\end{array}$ & $\begin{array}{l}\text { Meninos } \\
\text { NÃO }\end{array}$ & Meninas & $\begin{array}{l}\text { Ideias } \\
\text { Apenas as alunas } \\
\text { Mariana e Raquel } \\
\text { (conversam com a } \\
\text { família) }\end{array}$ & \\
\hline $\begin{array}{l}\text { "A gente não } \\
\text { conversa sobre } \\
\text { isso na classe." } \\
\text { Paulo }\end{array}$ & SIM & NÃO & $\begin{array}{l}\text { As meninas } \\
\text { conversam em } \\
\text { sala de aulas }\end{array}$ & $\begin{array}{l}\text { A maioria(meninos) } \\
\text { veem a memória } \\
\text { ligada a } \\
\text { lembranças de } \\
\text { datas pessoais. }\end{array}$ \\
\hline $\begin{array}{l}\text { "Na minha casa eu } \\
\text { nunca falei de } \\
\text { arte, sobre isto." } \\
\text { Gustavo }\end{array}$ & SIM & NÃO & $\begin{array}{l}\text { Os meninos se } \\
\text { preocupam com } \\
\text { jogos e musica } \\
\text { As meninas } \\
\text { reconhecem a } \\
\text { importância da } \\
\text { arte }\end{array}$ & $\begin{array}{l}\text { Apenas duas alunas } \\
\text { e um aluno } \\
\text { conversam com os } \\
\text { pais sobre arte e } \\
\text { pintores (os mais } \\
\text { conhecidos) }\end{array}$ \\
\hline $\begin{array}{l}\text { “A minha mãe } \\
\text { disse que pintura } \\
\text { é coisa de rico.” } \\
\text { Mariana }\end{array}$ & SIM & SIM & $\begin{array}{l}\text { As famílias } \\
\text { valorizam o } \\
\text { aspecto } \\
\text { econômico }\end{array}$ & $\begin{array}{l}\text { Independentemente } \\
\text { do artista, as } \\
\text { famílias não } \\
\text { frequentam } \\
\text { exposições e } \\
\text { museus. } \\
\text { Apenas duas alunas } \\
\text { e um aluno }\end{array}$ \\
\hline
\end{tabular}




\begin{tabular}{|c|c|c|c|c|}
\hline & & & & $\begin{array}{l}\text { frequentam o } \\
\text { museu de Barretos. }\end{array}$ \\
\hline $\begin{array}{l}\text { "A gente fala de } \\
\text { pintura em casa." } \\
\text { Vera }\end{array}$ & NÃO & SIM & $\begin{array}{l}\text { As meninas } \\
\text { conversam sobre } \\
\text { pintores } \\
\text { evidenciados pela } \\
\text { mídia. }\end{array}$ & $\begin{array}{l}\text { O poder de coersão } \\
\text { dos veículos de } \\
\text { comunicação de } \\
\text { massa, não são } \\
\text { percebidos por } \\
\text { ambos. }\end{array}$ \\
\hline $\begin{array}{l}\text { "Eu gosto de } \\
\text { pintura porque a } \\
\text { minha tia gosta. } \\
\text { Sueli }\end{array}$ & NÃO & SIM & $\begin{array}{l}\text { Os diálogos com } \\
\text { parentes é raro. }\end{array}$ & $\begin{array}{l}\text { As meninas } \\
\text { conversam apenas } \\
\text { com as mulheres } \\
\text { da família. }\end{array}$ \\
\hline $\begin{array}{l}\text { "A gente nunca } \\
\text { ouviu falar de } \\
\text { Vida Secas." } \\
\text { Marcos }\end{array}$ & SIM & SIM & $\begin{array}{l}\text { Apenas dois alunos } \\
\text { e duas alunas } \\
\text { conheciam a obra }\end{array}$ & $\begin{array}{l}\text { Apenas um aluno } \\
\text { conversou sobre a } \\
\text { obra e a leitura, } \\
\text { pelo interesse da } \\
\text { mãe (professora) } \\
\text { As alunas } \\
\text { conversaram sobre } \\
\text { o texto e as suas } \\
\text { falas, pois os pais } \\
\text { possuem nível } \\
\text { superior. }\end{array}$ \\
\hline $\begin{array}{l}\text { "Professor, as } \\
\text { figura são tristes." } \\
\text { Mônica }\end{array}$ & SIM & SIM & $\begin{array}{l}\text { Ambos identificam } \\
\text { sofrimento na } \\
\text { imagem } \\
\text { ("RETIRANTE") }\end{array}$ & $\begin{array}{l}\text { Apenas um aluno e } \\
\text { um aluna } \\
\text { conheciam a } \\
\text { imagem. }\end{array}$ \\
\hline $\begin{array}{l}\text { "Os desenhos não } \\
\text { tem não, ficam } \\
\text { parado.” Ary }\end{array}$ & SIM & SIM & $\begin{array}{l}\text { Ambos apresentam } \\
\text { dificuldades } \\
\text { quanto a } \\
\text { abordagem da } \\
\text { obra (movimento } \\
\text { e percepção de } \\
\text { cor) }\end{array}$ & $\begin{array}{l}\text { Apenas um aluno e } \\
\text { uma aluna fizeram } \\
\text { uma leitura lúdica } \\
\text { das imagens } \\
\text { apresentadas. }\end{array}$ \\
\hline
\end{tabular}


De acordo com o quadro acima, percebe-se que houve uma aceitação plena na proposta apresentada, pois todos os integrantes se esforçaram a romper com as dificuldades pessoais e a enfrentarem desafios, assim como a refletirem sobre seu grau de envolvimento (envolvendo os acertos também) e vivencias com as artes plásticas.

Há uma relação muito estreita entre os professores e alunos e a questão ficou evidenciada nas entrevistas do mês de Outubro, pois incentivamos sempre o dialógico nas relações, e o respeito as opiniões apresentadas. Os temas propuseram uma relação de intimidade com os autores e com a concepção artística da leitura, pois entramos também no campo do lúdico e de conceitos sobre cidadania, assim como sobre direitos e deveres sociais e políticos.

\begin{tabular}{|c|c|c|c|c|}
\hline Depoimentos & & & & \\
\hline & Meninos & Meninas & Ideias & \\
\hline $\begin{array}{l}\text { "Eu não entendi a } \\
\text { pergunta". Paulo } \\
\text { (perguntas: } 1 \text { e 2) }\end{array}$ & SIM & SIM & $\begin{array}{lr}\text { Ambos tiveram } \\
\text { dificuldades } & \text { em } \\
\text { entenderem } & \text { a } \\
\text { pergunta e em } & \text { em } \\
\text { responde-la } & \end{array}$ & 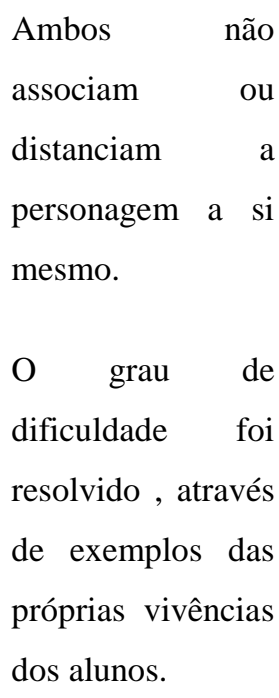 \\
\hline $\begin{array}{l}\text { "Eu nunca ouvi } \\
\text { falar no que o sem } \\
\text { senhor } \\
\text { perguntou."Ary }\end{array}$ & SIM & SIM & $\begin{array}{l}\text { Apenas um aluno } \\
\text { e duas alunas já } \\
\text { tinham ouvido } \\
\text { falar na } \\
\text { Constituição de } \\
1988 .\end{array}$ & $\begin{array}{l}\text { Ambos } \\
\text { reafirmaram } \\
\text { desinteresse pelo } \\
\text { tema, justificando } \\
\text { a faixa etária }\left(8^{\circ}\right. \\
\text { anos) }\end{array}$ \\
\hline
\end{tabular}




\begin{tabular}{|c|c|c|c|c|}
\hline $\begin{array}{l}\text { "Eu já falei sobre } \\
\text { isso com minha } \\
\text { mãe." Vera }\end{array}$ & NÃO & NÃO & $\begin{array}{l}\text { Apenas uma aluna } \\
\text { e um aluno } \\
\text { demonstraram } \\
\text { conhecimento } \\
\text { sobre o assunto } \\
\text { (com maior } \\
\text { conhecimento) }\end{array}$ & $\begin{array}{ll}\text { Percebe-se que } & \text { o } \\
\text { tema não } & \text { é } \\
\text { discutido } & \text { no } \\
\text { ensino } & \\
\text { fundamental. } & \end{array}$ \\
\hline $\begin{array}{l}\text { "Eu nunca tinha } \\
\text { ouvido falar em ... } \\
\text { em... cultura desse } \\
\text { jeito." Marcelo }\end{array}$ & SIM & SIM & $\begin{array}{l}\text { Ambos não } \\
\text { identificam a } \\
\text { questão da cultura } \\
\text { e do Patrimônio } \\
\text { como reflexo de } \\
\text { um país. }\end{array}$ & $\begin{array}{lr}\text { A cultura } & \text { e } \\
\text { Patrimônio } & \\
\text { (material } & \text { e } \\
\text { imaterial) } & \text { são } \\
\text { raramente } & \\
\text { discutidos. Os } \\
\text { alunos e alunas } \\
\text { não são instigados } \\
\text { sobre o tema. }\end{array}$ \\
\hline $\begin{array}{l}\text { "Professor, coisa } \\
\text { estranha" Paulo }\end{array}$ & SIM & SIM & $\begin{array}{l}\text { Ambos } \\
\text { apresentaram } \\
\text { dificuldades em } \\
\text { localizar ou } \\
\text { identificar as falas } \\
\text { com a questão do } \\
\text { Patrimônio } \\
\text { Imaterial }\end{array}$ & \\
\hline
\end{tabular}

Percebe-se que, por timidez e medo, o protagonismo das discussões sempre se restringe a um pequeno grupo de alunos e estes provocam, não apenas admiração, como estimulo a futuras participações dos outros. A questão da identificação das falas do texto em relação ao Patrimônio Imaterial gerou muita comicidade, pois a partir dos exemplos citados, os alunos se soltaram e começaram a fazer associações como seu cotidiano.

A educação patrimonial é de sua importância pois os alunos são instigados a repensarem suas origens e a sua própria comunidade a qual participam, por isso, segundo Funari e Pelegrini, comunidade e ser norteada pela delimitação democrática dos bens reconhecidos como merecedores de preservação. Mas a relação dos bens a serem tombados precisa estar integrada aos marcos identitários reconhecidos 
pela própria comunidade na qual se inserem. (FUNARI E PELEGRINI, 2009, p. 59)

Para encerrar, gostaria de destacar que a leitura dramática foi decisiva para o processo de amadurecimento destes(as) alunos(as), pois através dela foi possível vivenciar experiências, que até então permaneciam apena no plano do devaneio e da idealização. Sua realização reafirma a condição em ampliar a atuação do teatro dentro da Escola Estadual Antônio Olympio para a expansão das aulas em outros níveis de aprendizado, ou seja, as aulas não se restringirão ao ensino fundamental.

\section{ANÁLISE E DISCUSSÕES DE RESULTADOS}

Destacamos que os alunos(as) da Escola Estadual Antônio Olympio, conseguiram não apenas realizarem as apresentações da leitura dramática "Vidas Secas", com duas sessões (com debate com o público) mas também concluíram com empenho e dedicação as atividades da oficina que propunha um estudo sobre a educação patrimonial.

Um dos grandes e graves problemas da relação dos(as) alunos(as) com o orientador foi superado, ou seja, a dificuldade em incorporar a leitura em ações, dentro e fora da escola. Hoje, vivenciamos na prática a relação com as altas tecnologias (muitas vezes de forma equivocada), pois a EAD, é um fato inquestionável em nosso país.

$\mathrm{O}$ assunto abordado foi discutido e analisado, assim como vivenciado com propriedade e nos auxiliou de forma positiva em várias questões, principalmente em nos permitir entrar em contato com vários autores e com as obras de Candido Portinari, que juntamente com Graciliano Ramos - através da obra "Vidas Secas" - nos instigaram a refletir e experimentar a interface entre as artes visuais e as poéticas da cena.

Este fato contrasta com a relação em trabalharmos com alunos(as) que não apenas não frequentam exposições ou museus, e que não conheciam também tais artistas, mas ignoravam o fato de que precisamos aprender anos ver e enxergar não apenas como sujeito, ou cidadão, mas como ser social. As instituições estão vinculadas com o poder capitalista (favor que sustenta e favorece a chamada burguesia).

Contudo, para propormos uma busca pela autonomia ao grupo (analisado e estudado) que mantém (ainda) condicionamentos sociais, que os levam a se verem como 
seres "incapazes" (pela pouca idade) e "improdutivos" foi necessário fazê-los refletir que era possível mudarem seu cotidiano, assumindo responsabilidades, primeiramente com eles mesmos.

A escola hoje pode e deve levar alunos (alunas) e educadores a acreditarem que, segundo Freire, "ensinar exige curiosidade" assim como:

\begin{abstract}
o exercício da curiosidade convoca a imaginação, a intuição, as emoções, a capacidade de conjecturar, de comparar, na busca da perfilização do objeto ou do achado de sua razão de ser. Um ruído, por exemplo, pode provocar minha curiosidade. Observo o espaço onde parece que se está verificando. Aguço o ouvido. Procuro comparar com outro ruído cuja razão de ser já conheço. (FREIRE, 2011, p . 85)
\end{abstract}

Dentre as ações práticas executadas destacamos a necessidade em podermos interpretar o texto "Vidas Secas" com maior propriedade, estabelecendo relações entre o texto e o nosso patrimônio material e patrimônio imaterial, assim como em podermos também visualizar a nossa relação com o olhar e com os movimentos e a importância das cores em determinadas obras, determinados desenhos ou pinturas.

Uma de nossas maiores conquistas é poder vivenciar, segundo Courtney (2006) que:

\footnotetext{
o teatro é a base de toda educação criativa. Dele fluem todas as artes. O homem primitivo expressou-se antes dramaticamente: dançava mimeticamente, criando os sons. Depois necessitou a arte para pintar-se, ou cobrir-se com peles de animais, ou magicamente representar suas ações nas paredes das cavernas; e a música foi essencial para dar ritmo e tempo à sua dança dramática. (COURTNEY, 2006, p. 56)
}

Portanto, entendemos que uma das maiores conquistas é poder questionar, discutir, e avaliar esta questão, pois todo processo artístico maduro explicita que as mudanças de pensamento e de ação é possível, mas a pequeno, médio e longo prazo. 


\section{CONSIDERAÇÕES FINAIS}

Este trabalho investigativo ou estudo nos deu condições de reafirmar que não pretendemos, por meio de nossa proposta, apresentar modelos, e/ou resolubilidade para questões que envolvem alunos(as) que apresentam dificuldades em assumir responsabilidades; dificuldade em concentração, medo, baixa auto-estima, entre outros. No entanto, propomos construir juntamente com eles e elas, através do teatro, ações que os(as) levem a vivenciar que o importante é a relação que mantemos não apenas com a visualidade, mas também como os nossos patrimônios materiais ou imateriais, assim como culturais.

Contudo, para propormos uma libertação de condicionamentos sociais, ou estereótipos, criados pela sociedade capitalista - o homem tornou-se mercadoria - nossos alunos e alunas tiveram que, com ações desafiadoras, passarem a refletir e a vivenciar não somente a importância da arte, e da educação patrimonial, mas também a investigar qual o papel da escola, principalmente no ensino fundamental e a função dos veículos de comunicação de massa, que criam necessidades e nos enxergam como seres de "fácil" controle social, levando-nos a mais ações inconscientes - reforçando estereótipos e ditando regras comportamentais - não apenas nas salas de aula.

Hoje, o ensino fundamental deve propor ações educacionais que instiguem a reciprocidade, a vivencia de coletividade, o respeito aos novos paradigmas, pois as ações do hoje reverberam amanhã. Precisamos rever e respeitar as etapas escolares, assim como refletir, e entender também o histórico pessoal de cada aluno e aluna, não julgando-o (a) mas sim instigando-o (a) a descobrir suas potencialidades, seus limites e propor saídas para enfrentar e superar as dificuldades apresentadas, pois o "erro" (em exercícios de improvisação e outros) é uma grande e excelente fonte de aprendizado, capaz de nos estimular a uma autonomia em nossas ações,

Percebe-se que ainda vivenciamos o ensino de teatro dentro das instituições de ensino como apêndice ou atividades complementares, indo na contramão da lei, pois ainda prevalece nas instituições a não obrigatoriedade do teatro como disciplina hegemônica. Perante as ações práticas executadas pelos(as) alunos(as) como também a realização de duas apresentações - leitura dramática - nos perguntamos: Por que será que, 
nas apresentações, temos um número limitado de educadores, pais e familiares? E por que o número de educadores aumenta quando temos critérios de vantagens curriculares? A demanda de profissionais da educação em espetáculos de alunos(as) é reduzida quando não há critérios de gratificações.

Urge entender que é necessária uma mudança madura, prática, na forma da sociedade (assim como os profissionais da educação e a todos os profissionais das Instituições públicas e particulares, desde faxineiras à coordenação pedagógica) lidar e conviver com alunos(alunas) principalmente no ensino fundamental, pois precisamos estimular, instigar e respeitar todo trabalho artístico que prioriza a qualidade artística em suas mais diversas manifestações e mostrar que "A arte possibilita ao ser humano repensar suas certezas e reinventar seu cotidiano" (AZEVEDO, 2009, p .335).

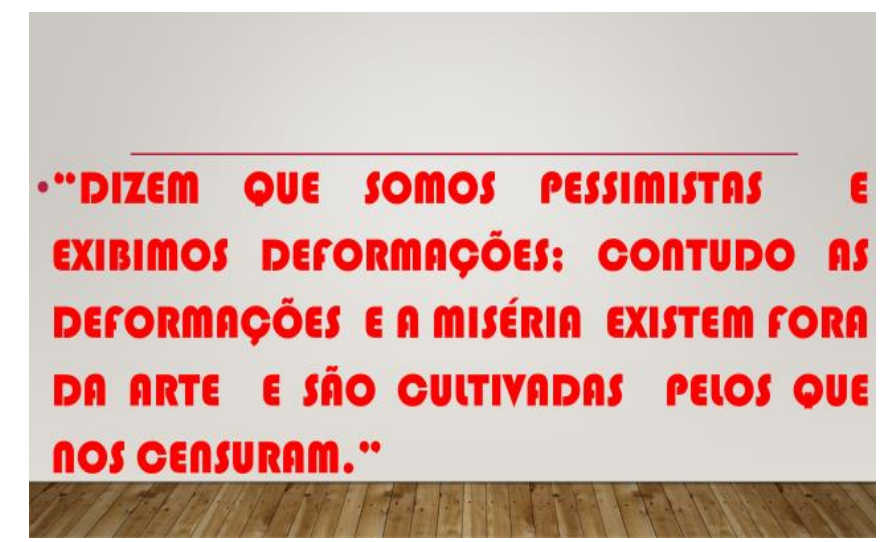

Figura 7: Frase da carta de Ramos à Portinari - Fonte: elaboração própria

Assim, é fundamental salientar que, a cada etapa do trabalho, evidenciou-se que nosso processo está em constante construção e transformação, por isso, não se encerra por aqui. A nossa realidade está em plena mudança, assim como todos os alunos e alunas envolvidos(as) no trabalho, em função disso, reafirmamos: Enxergamos o mundo de que forma? Por meio dos olhos ou do cérebro? São questões atualmente discutidas por estudiosos, por autores importantes, por nós em nossas ações práticas (oficina teatral) e por profissionais que almejam por mudanças, sejam micro, ou macro mudanças, pois todas as ações do homem são políticas por natureza e a educação e a cultura são a identidade de um povo e de uma nação. 


\section{REFERÊNCIAS}

AZEVEDO, Fernando Antônio G. A arte possibilita ao ser humano repensar suas certezas e reinventar seu cotidiano. (orgs.) BARBOSA, Ana Mae; COUTINHO, Rejane Galvão - São Paulo: Ed, UNESP, 2009

BALBI, Marilia. Paulicéia - Portinari - o pintor do Brasil. Boitempo Editorial, São Paulo; 2003.

BARBOSA, Ana Mae. A arte contribui muito para desenvolver o sentido de cidadania. Entrevista Programa Roda Viva, 12 /10 /1998. Disponível em <http: / /www.rodaviva. fatesp.br>. Acesso em 14/11/2009.

BOAL, Augusto. Jogos para atores e não atores - $13^{\mathrm{a}} \mathrm{Ed}-$ Rio de Janeiro; Civilização Brasileira, 2009.

de Janeiro: Civilização Brasileira, 1983.

CALLADO, Antônio et al. Candido Portinari: o lavrador de quadros - Projeto Portinari; PUC- Rio de Janeiro, 2003.

COURTNEY, Richard. Jogo, teatro \& pensamento. Tradução: MULLER Karen Astrid, GARCIA, Silvana: Perspectiva, São Paulo; 2006

DESLANDES, Suely Ferreira: Pesquisa Social: Teoria, método e criatividade/ Suely Ferreira Deslandes, Romeu Gomes; Maria Cecília de Souza Minayo (organizadora). 29ª Ed - Petropólis, Rj: Vozes, 2010.

DIAS, Belidson. Apagamentos: ei,ei,ei...cultura o que? Visual? E as Belas Artes, Artes Plásticas e Artes Visuais? In: Imagem, poéticas visuais e processos de mediação, 2007, Goiânia. Cadernos de recursos - 8ºminário de Pesquisas. Goiânia: UFG, 2007.

FREIRE, Paulo. Pedagogia da autonomia: saberes necessários à prática educativa. São Paulo: Paz e Terra, 2011.

-------------. Pedagogia do Oprimido, Rio de Janeiro, Paz e Terra:2005.

FISCHER, Ernst. A Necessidade da Arte. 9. Ed - Rio de Janeiro: Ltc, 2007.

FUNARI, Pedro Paulo, PELEGRINI, Sandra. C.A. Patrimônio Histórico e Cultural. $2^{\text {a }}$ ed - Rio de Janeiro: Jorge Zahar Ed,2009.

JAPIASSU, Ricardo. Metodologia do ensino de teatro. Campinas - São Paulo: Papirus Editora, 7 ${ }^{\text {a }}$ Edição, 2001.

LEVI, Clovis. Teatro Brasileiro - Um panorama do Século XX. Rio de Janeiro: Funarte: São Paulo: Atração Produções ilimitadas, 1997.

MACIEL, Diva Albuquerque, BARBATO Silviane, Desenvolvimento humano, educação e inclusão social. Ed. UNB - Brasília, 2015. Disponível em: http: // www.ead.unb.br/moodle2013/pluginfile.php/79187/modresource/content/1/livro\%20De senvolvimento\%20Humano.pdf>-acesso em Agosto de 2018. 
MARTINS, Raimundo. Por que e como falamos da Cultura Visual? VisualidadesRevista do programa de mestrado em cultura visual, 2006. Disponível em: https://www.revistas.ufg.br/VISUAL/article/view/17999 - Acesso em Maio de 2018.

Santa Maria: UFSM, 2017.

et alli. Pensamento e Investigação em Arte e Educação. , TOURINHO, Irene (org.). Processos \& Práticas de Pesquisa em Cultura Visuais \& Educação. Santa Maria, Ed. UFSM, 2013.

MEDEIROS, Ana Elisabete de Almeida. Educar, participar e preservar. Unb. Disponível em https://aprender.ead.unb.br/pluginfile.php/528597/mod_resource/content/3/Cap\%C3\%A Dtulo\%204\%20-\%20Educar\%2C\%20participar\%20e\%20preservar.pdf . Acesso em Junho de 2018

América Latina - Identidades plurais, identidade única; UNB https://aprender.ead.unb.br/pluginfile.php/528587/mod_resource/content/1/Capítulo\%2 01\%20-\%20América\%20Latina\%20$\%$ 20Identidades\%20plurais\%2C\%20identidade\%20única\%3F.p. Acesso em Junho de 2018.

Culturali

Natureza e Cultura - Paisagem https://aprender.ead.unb.br/pluginfile.php/528589/mod_resource/content/2/Cap\%C3\%A Dtulo\%202\%20$\% 20$ Natureza\%20e\%20Cultura\%20\%E2\%80\%93\%20paisagem\%20cultural\%3F.pdf. Acesso em Junho de 2018. 2010

MILARÉ, Sebastião. Antunes Filho: poeta da cena. São Paulo: Edições Sesc sp,

NIELSEN, Alan. Caminhando com Portinari. São Paulo, Terra Virgem, 2012.

PELEGRINI, Sandra C. A. Patrimônio cultural: consciência e preservação. São Paulo: Editora Brasiliense, 2009.

PINHEIRO, Lenise. Fotografia de Palco. - São Paulo: Editora Senac São Paulo Edições SESC SP, 2008.

RAMOS, Graciliano. Vidas Secas. 87 Ed - Rio de Janeiro: Record, 2002.

ROSA, Nereide Schilaro Santa. Candido Portinari - São Paulo: Moderna, 1999.

SÉRVIO, Pablo Petit Passos. O que estudam os estudos de cultura visual? 2014, Disponível em: https://periodicos.ufsm.br/revislav/article/view/12393 - Acesso em Setembro de 2018.

SUASSUNA, Ariano. Iniciação à Estética, São Paulo, Ed. José Olympio, $6^{\text {a }}$ edição, capítulo 25, 2004.

URRUTIGARAY, Maria Cristina. Arteterapia: A transformação pessoal pelas imagens. Rio de Janeiro: Ed Wak, 2008. 


\section{APÊNDICES}

A - Roteiro de entrevista (mês de Setembro)

\section{Entrevista I}

1- O que nos faz acreditar na importância de um artista?

2- Será que devemos nos satisfazer apenas com as informações da mídia sobre determinados artistas ou escritores?

3- Será que nosso país respeita nossa memória? E você, respeita-a? De que forma?

4- Qual a importância da memória para um país e para a sua cultura?

5- Como as imagens estudadas nos chamam ou nos chamaram à atenção?

6- Será que as imagens possuem movimento e nos emocionam? Comente.

7- O que nos impressiona nas imagens da obra "Retirantes"(1944)?

B - Roteiro de entrevista (mês de Outubro)

\section{Entrevista II}

1- Nos reconhecemos nos exemplos citados pelo autor em relação as personagens? Qual a relação que as personagens mantém com seus objetivos? Essas relações existem? Cite-as.

2- Como podemos contribuir para que o Estado cumpra com seus deveres e com os seus direitos? E como devemos cuidar de nossos direitos e deveres também?

3- Você já conhecia ou somente ouviu falar na Constituição de 1988 ?

4- Quais as falas que apresentam relação com o Patrimônio Material e Patrimônio Imaterial? 


\section{ANEXOS}

\section{Fotos}

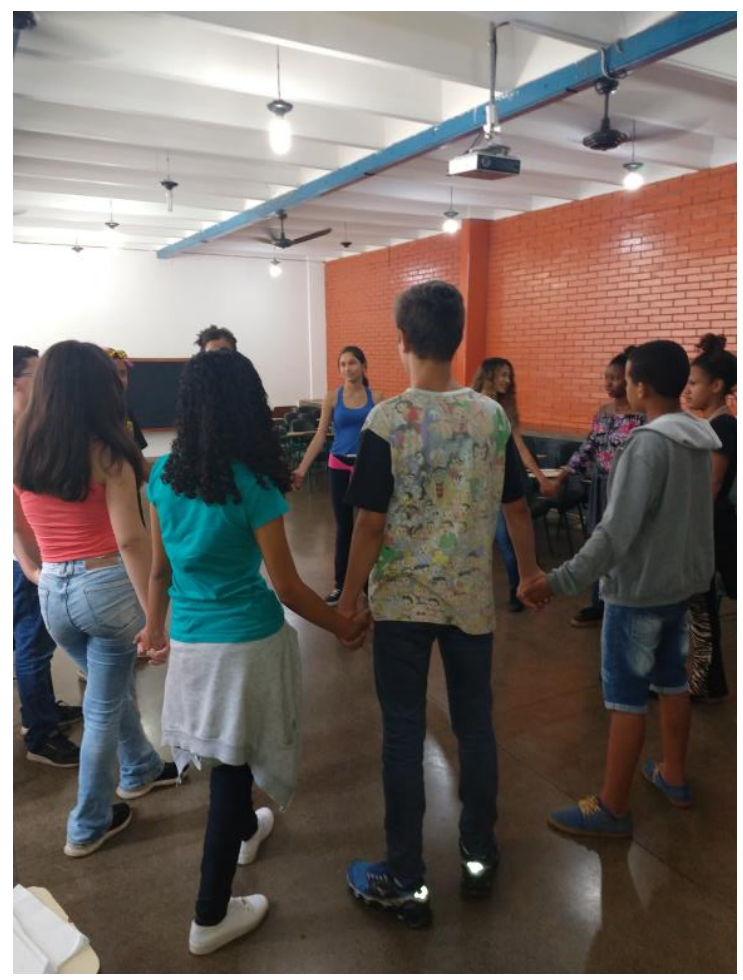

Imagem 01. Exercícios de sensibilização

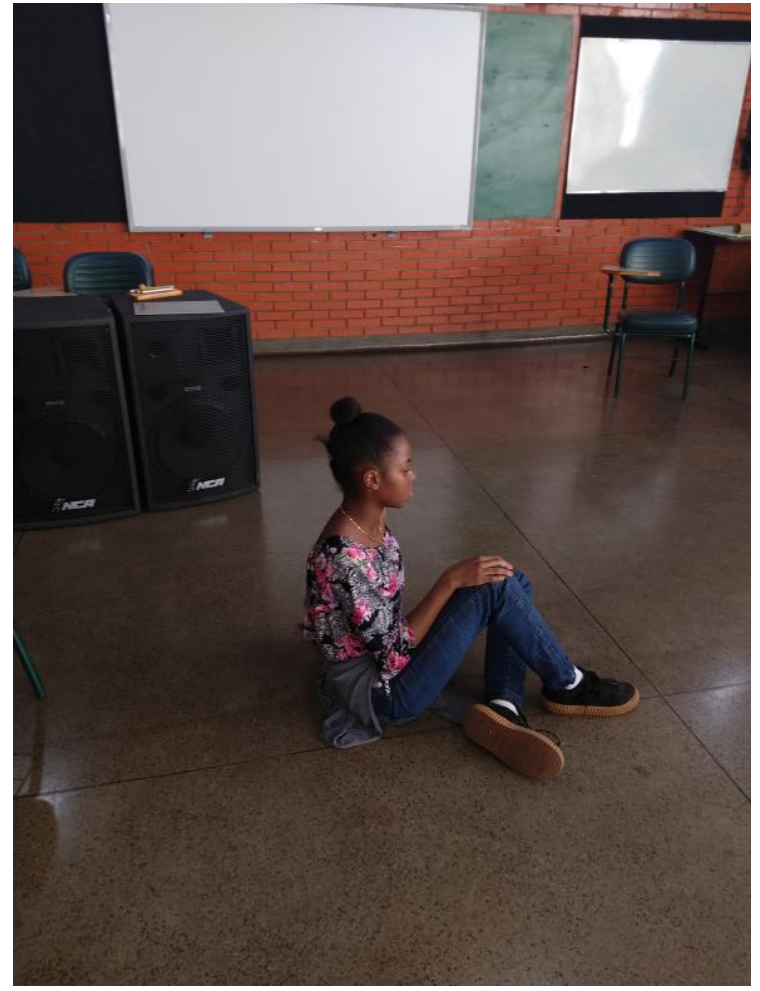

Imagem 2.Estudo de imagens para Leitura Dramática 


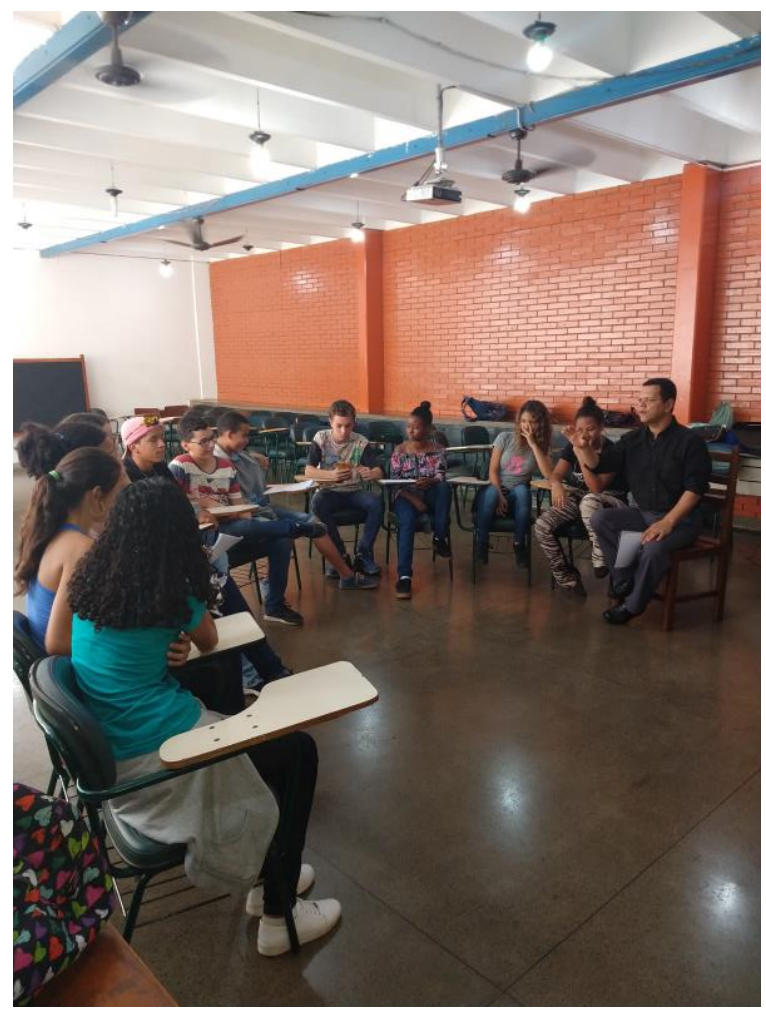

Imagem 3. Um dos encontros.

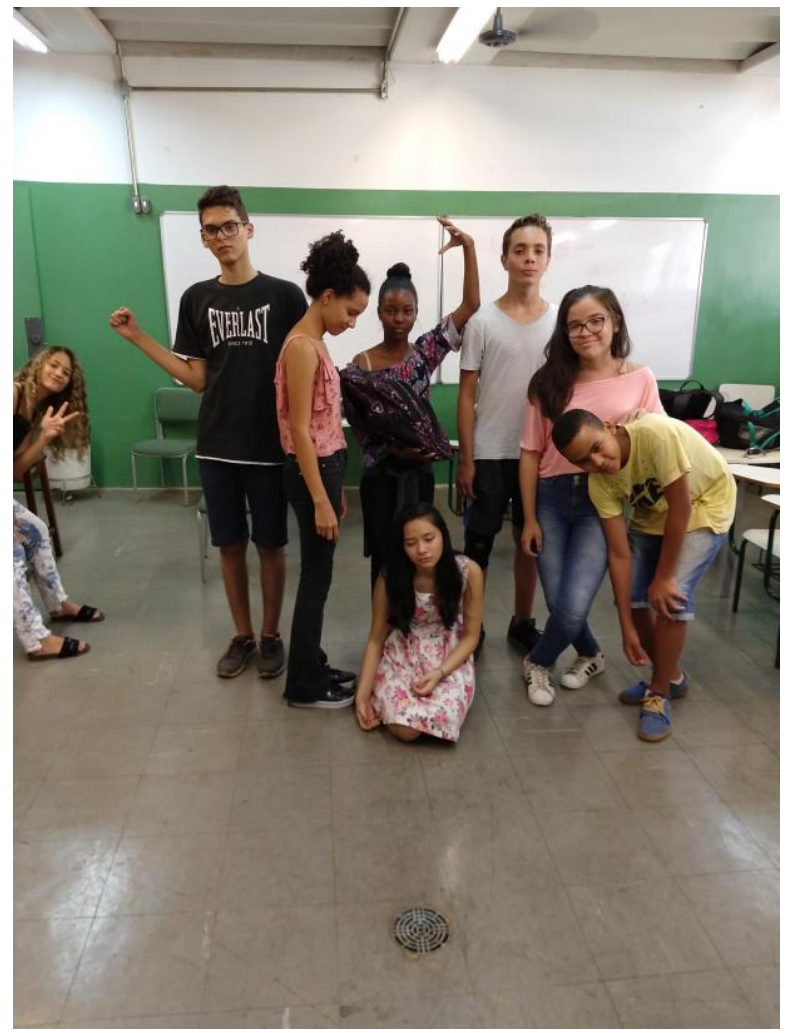

Imagem4. Exercício corporal 


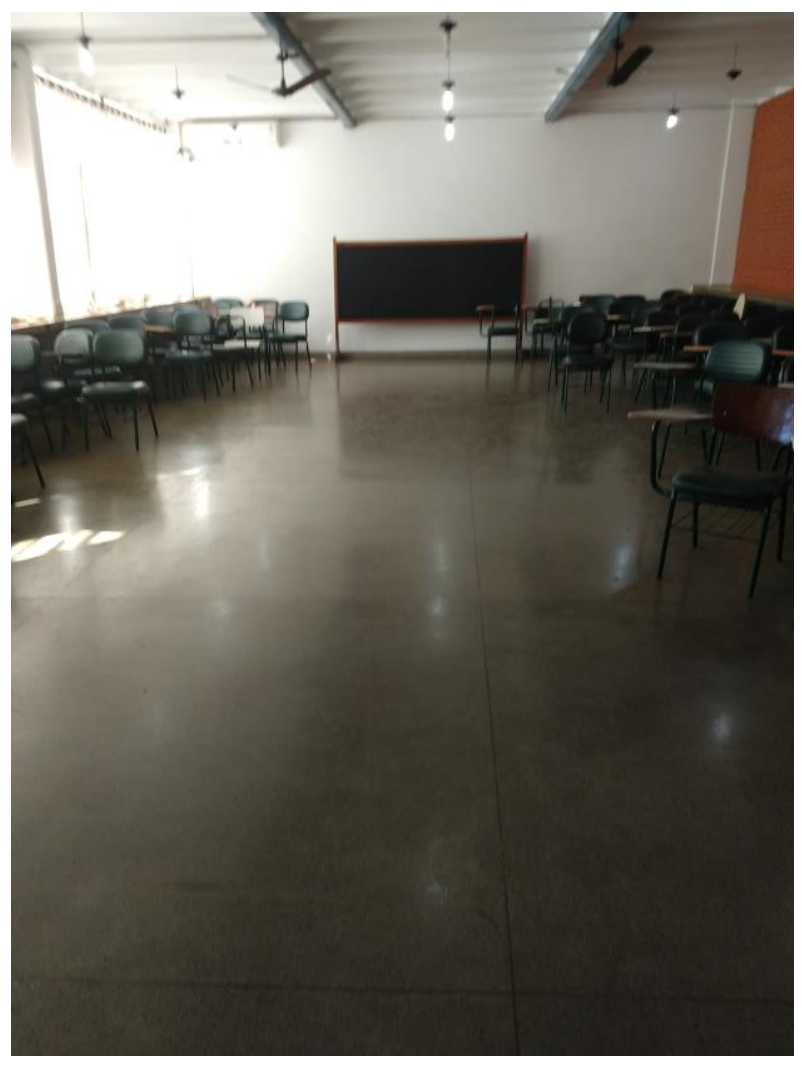

Imagem 5. Espaço para ensaios. 


\section{Termos de cessão de direitos}

A seguir, cópias digitalizadas dos termos de cessão de direitos autorais pelo uso de imagem e áudio dos alunos cujas imagens aparecem nas fotos acima utilizadas, o que equivale a dizer que não foram anexados os termos de cessão de uso dos alunos que não se fazem presentes nas imagens. 
Pelo presente instrumento particular de cessão de direitos autorais,

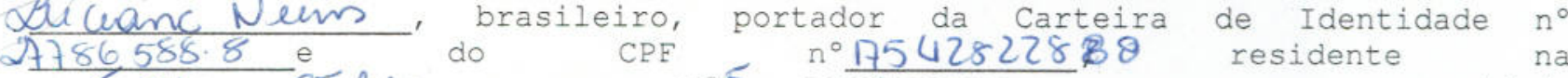

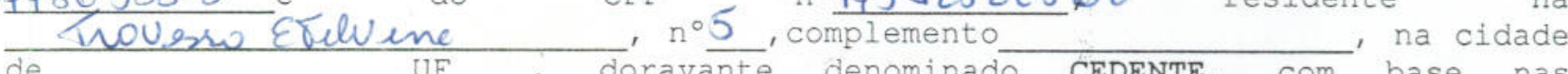
de UF, doravante denominado CEDENTE, com base nas disposições da Lei $9.6 \overline{10 / 9} 8$, CEDE de forma integral, definitiva e gratuita, à Universidade de Brasilia - UnB, Instituição Federal de Ensino Superior, inscrita no CNPJ sob o n. 00.038.174/0001-43, todos os direitos autorais patrimoniais sobre o conteúdo pesquisado e o material didático produzido pelo Curso de Especialização em Educação e Patrimônio Cultural, mediante as condições abaixo que, voluntariamente, aceita e outorga:

Cláusula Primeira - A presente cessão de direitos autorais é feita a título gratuito, sem qualquer remuneração ou compensação e possui caráter irrevogável e irretratável.

Cláusula Segunda - A presente cessão de direitos autorais confere à UnB 0 direito de utilizar, no todo ou em parte, o conteúdo pesquisado e o material didático produzido peloEduardo Nunte pelo professor vladimir Corrêa Fonseca N como the aprouver, sob qualquer modalidade, incluindo, mas não se limitando, à reproduçăo, divulgação, promoção, produção de mídia ou qualquer outro meio, desde que não vedado em Lei.

Cláusula Terceira - A UnB poderá promover quantas edições do material forem necessárias, bem como a sua distribuição no mercado nacional ou exterior.

Cláusula Quarta - o CEDENTE declara que o conteúdo do material produzido, objeto da presente cessão, é de sua exclusiva autoria, sendo titular e detentora dos direitos autorais sobre mesmo, razão pela qual assume inteira responsabilidade por eventual reivindicação desses direitos por parte de terceiros ou questionamentos judiciais ou extrajudiciais decorrentes de sua divulgação.

Cláusula Quinta - A UnB poderá promover o registro do material produzido nos termos do art. 19 da Lei n $9.610 / 1998$.

Cláusula sexta - A presente cessão de direitos autorais patrimoniais vigorará pelo prazo de 05 (cinco) anos, contados da data de assinatura deste Instrumento, podendo ser renovada pelo CEDENTE, por interesse da UnB.

E assim, por estar de acordo com todas as condiçöes deste Termo de Cessão de Direitos Autorais, firma o presente em duas vias, de igual teor e forma, para um só efeito na presença das testemunhas abaixo.

Nome do responsável

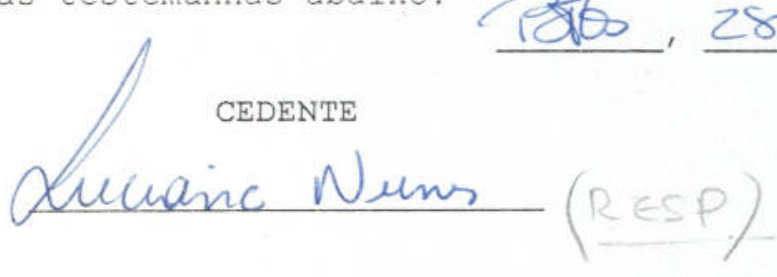

CESSIONÁRIA -Nome do aluno (a)

Aluno Pesquisador do Curso de Especialização em Educação e Patrimônio Cultural

\section{(A INTEREACE ENTRE AS ARTES VISUAIS E AS POETICAS DA CENA)}

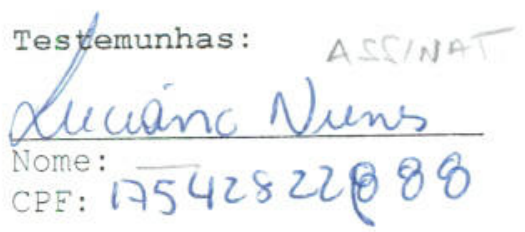




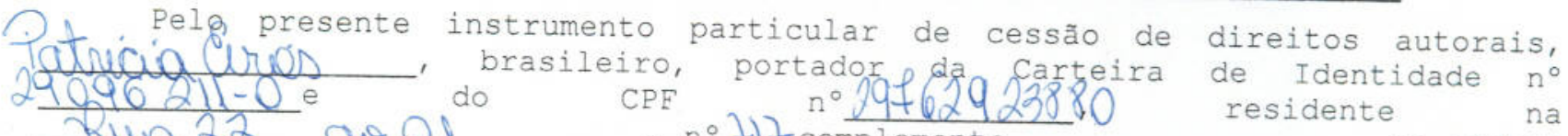

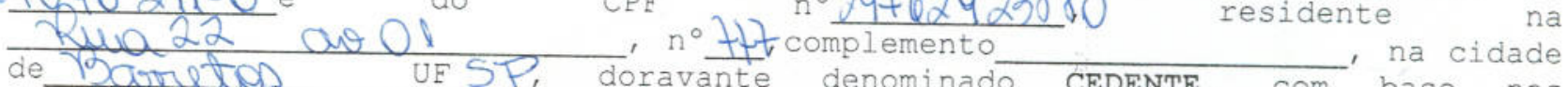
disposições da Lei $9.6 \overline{10 / 98}$, Ceravante denominado CEDENTE, com base nas Universidade de Brasília dorma integral, definitiva e gratuita, à Universidade de Brasilia - UnB, Instituição Federal de Ensino Superior, inscrita no CNPJ sob o n. 00.038.174/0001-43, todos os direitos autorais patrimoniais sobre o conteúdo pesquisado e o material didático produzido pelo Curso de Especialização em Educação e Patrimônio Cultural, mediante as condições abaixo que, voluntariamente, aceita e outorga:

Cláusula Primeira - A presente cessão de direitos autorais é feita a título gratuito, sem qualquer remuneração ou compensação e possui caráter irrevogável e irretratável.

Cláusula Segunda - A presente cessão de direitos autorais confere à UnB o direito de utilizar, no todo ou em parte, o conteúdo pesquisado e o material didático produzido pelo e pelo professor vladimir Corrêa Fonseca___ como the aprouver, sob qualquer modalidade, incluindo, mas não se limitando, à reprodução, divulgação, promoção, produção de mídia ou qualquer outro meio, desde que não vedado em Lei.

Cláusula Terceira - A UnB poderá promover quantas edições do material forem necessárias, bem como a sua distribuição no mercado nacional ou exterior.

Cláusula Quarta - O CEDENTE declara que o conteúdo do material produzido, objeto da presente cessão, é de sua exclusiva autoria, sendo titular e detentora dos direitos autorais sobre mesmo, razão pela qual assume inteira responsabilidade por eventual reivindicação desses direitos por parte de terceiros ou questionamentos judiciais ou extrajudiciais decorrentes de sua divulgação.

Cláusula Quinta - A UnB poderá promover o registro do material produzido nos termos do art. 19 da Lei n $9.610 / 1998$.

Cláusula sexta - A presente cessão de direitos autorais patrimoniais vigorará pelo prazo de 05 (cinco) anos, contados da data de assinatura deste Instrumento, podendo ser renovada pelo CEDENTE, por interesse da UnB.

E assim, por estar de acordo com todas as condições deste Termo de Cessão de Direitos Autorais, firma o presente em duas vias, de igual teor e forma, para um só efeito na presença das testemunhas abaixo.

Barrtos, 28 de 112018

CEDENTE

Nome do responsável
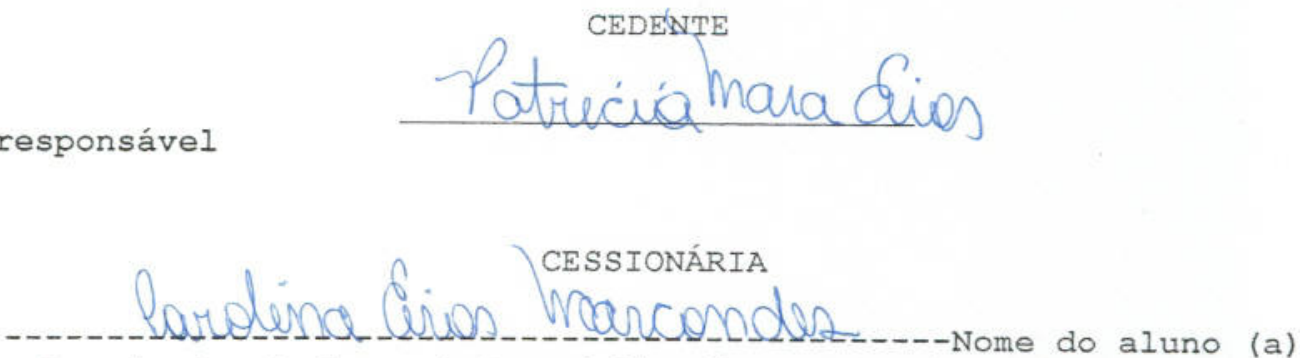

Aluno Pesquisador do Curso de Especialização em Educação e Patrimônio Cultural

\section{(A INTERFACE ENTRE AS ARTES VISUAIS E AS POETICAS DA CENA)}

Testemunhas:

Nome:

$\mathrm{CPE}$ :
Nome:

$\mathrm{CPF}$ : 
Pelo presente instrumento particular de cessão de direitos autorais, Guloin , brasileiro, portador da Carteira de Identidade n 7 do $\mathrm{CPF}$ n 21568.692 foresidente na Rodoria ASSIS CHATOBPAN, no377, complemento KM M O I na cidade de Redouvic ASSIf-BtouF SP, doravante denominado CEDENTE, com base nas disposições da Lei 9.610/98, CEDE de forma integral, definitiva e gratuita, à Universidade de Brasilia - UnB, Instituição Eederal de Ensino Superior, inscrita no CNPJ sob o n. 00.038.174/0001-43, todos os direitos autorais patrimoniais sobre o conteúdo pesquisado e o material didático produzido pelo Curso de Especialização em Educação e Patrimônio Cultural, mediante as condições abaixo que, voluntariamente, aceita e outorga:

Cláusula Primeira - A presente cessão de direitos autorais é feita a título gratuito, sem qualquer remuneração ou compensação e possui caráter irrevogável e irretratável.

Cláusula Segunda - A presente cessão de direitos autorais confere à UnB o direito de utilizar, no todo ou em parte, o conteúdo pesquisado e o material didático produzido pelo e pelo professor vladimir Corrêa Fonseca , como the aprouver, $\overline{s o b}$ qualquer modalidade, incluindo, mas não se limitando, à reprodução, divulgação, promoção, produção de mídia ou qualquer outro meio, desde que não vedado em Lei.

Cláusula Terceira - A UnB poderá promover quantas edições do material forem necessárias, bem como a sua distribuição no mercado nacional ou exterior.

Cláusula Quarta - O CEDENTE declara que o conteúdo do material produzido, objeto da presente cessão, é de sua exclusiva autoria, sendo titular e detentora dos direitos autorais sobre mesmo, razão pela qual assume inteira responsabilidade por eventual reivindicação desses direitos por parte de terceiros ou questionamentos judiciais ou extrajudiciais decorrentes de sua divulgação.

Cláusula Quinta - A UnB poderá promover o registro do material produzido nos termos do art. 19 da Lei $n^{\circ} 9.610 / 1998$.

Cláusula sexta - A presente cessão de direitos autorais patrimoniais vigorará pelo prazo de 05 (cinco) anos, contados da data de assinatura deste Instrumento, podendo ser renovada pelo CEDENTE, por interesse da UnB.

E assim, por estar de acordo com todas as condições deste Termo de Cessão de Direitos Autorais, firma o presente em duas vias, de igual teor e forma, para um só efeito na presença das testemunhas abaixo.

Barretos, 28 de 112018

Nome do responsável
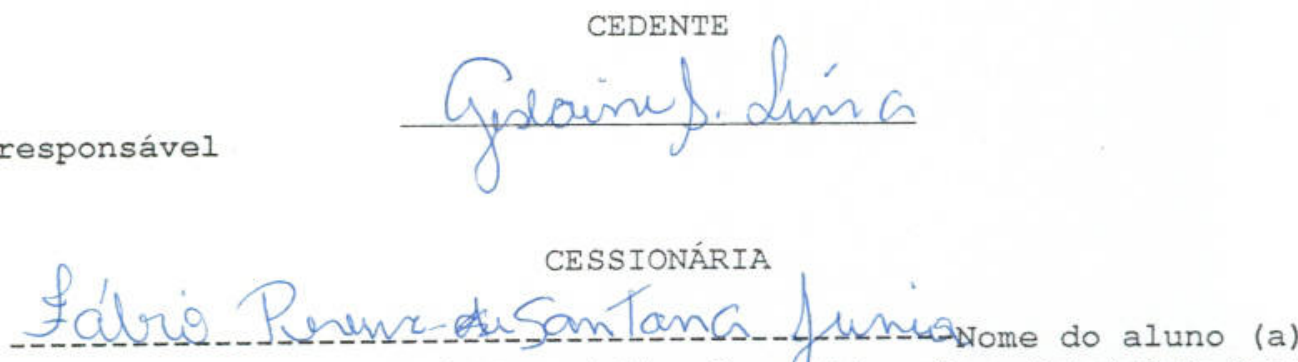

Aluno Pesquisador do Curso de Especialização em Educação e Patrimônio Cultural

\section{(A INTEREACE ENTRE AS ARTES VISUAIS E AS POETICAS DA CENA)}

Testemunhas:

Nome:

CPE:
Nome:

$\mathrm{CPE}$ : 


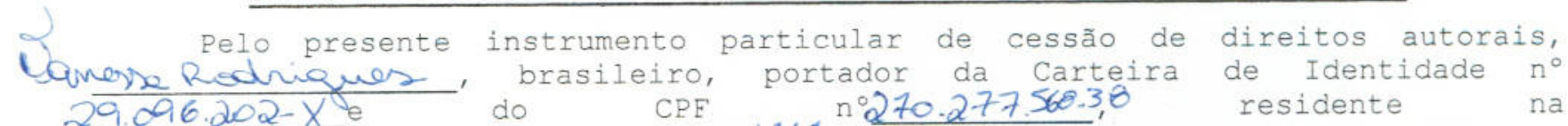

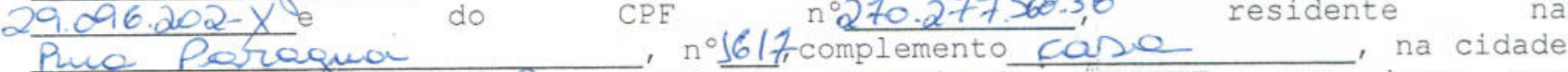
de Borretor UFS.P, doravante denominado CEDENTE, com base nas disposições da Lei $9.6 \overline{10 / 9}$, CEDE de forma integral, definitiva e gratuita, à Universidade de Brasilia - UnB, Instituição Eederal de Ensino Superior, inscrita no CNPJ sob o n. 00.038.174/0001-43, todos os direitos autorais patrimoniais sobre o conteúdo pesquisado e o material didático produzido pelo Curso de Especialização em Educação e Patrimônio Cultural, mediante as condições abaixo que, voluntariamente, aceita e outorga:

Cláusula Primeira - A presente cessão de direitos autorais é feita a título gratuito, sem qualquer remuneração ou compensação e possui caráter irrevogável e irretratável.

Cláusula segunda - A presente cessão de direitos autorais confere à UnB 0 direito de utilizar, no todo ou em parte, o conteúdo pesquisado e 0 material didático produzido pelo e pelo professor vladimir Corrêa

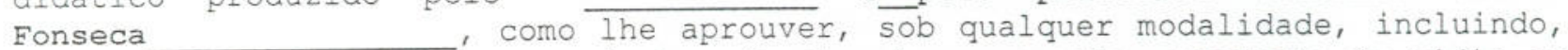
mas não se limitando, à reprodução, divulgação, promoção, produção de mídia ou qualquer outro meio, desde que não vedado em Lei.

Cláusula Terceira - A UnB poderá promover quantas edições do material forem necessárias, bem como a sua distribuição no mercado nacional ou exterior.

Cláusula Quarta - o CEDENTE declara que o conteúdo do material produzido, objeto da presente cessão, é de sua exclusiva autoria, sendo titular e detentora dos direitos autorais sobre mesmo, razão pela qual assume inteira responsabilidade por eventual reivindicação desses direitos por parte de terceiros ou questionamentos judiciais ou extrajudiciais decorrentes de sua divulgação.

Cláusula Quinta - A UnB poderá promover o registro do material produzido nos termos do art. 19 da Lei $n^{\circ} 9.610 / 1998$.

Cláusula sexta - A presente cessão de direitos autorais patrimoniais vigorará pelo prazo de 05 (cinco) anos, contados da data de assinatura deste Instrumento, podendo ser renovada pelo CEDENTE, por interesse da UnB.

E assim, por estar de acordo com todas as condições deste Termo de Cessão de Direitos Autorais, firma o presente em duas vias, de igual teor e forma, para um só efeito na presença das testemunhas abaixo.

Bareater, 29,11 de_2018

\section{CEDENTE}

Nome do responsável

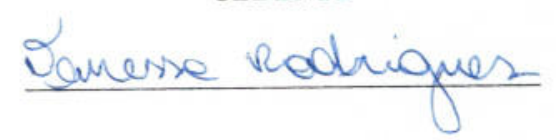

CESSIONÁRIA

Siniviz Gabrel do Siluo Roglriguez-Nome do aluno (a)

Aluno Pesquisador do Curso de Especialização em Edưcação e Patrimônio Cultural

\section{(A INTEREACE ENTRE AS ARTES VISUAIS E AS POETICAS DA CENA)}

Testemunhas: 
TERMO DE CESSÃO DE DIREITOS AUTORAIS PELO USO DE IMAGEM E ÁUDIO

Pelo presente instrumento particular de cessão de direitos autorais,

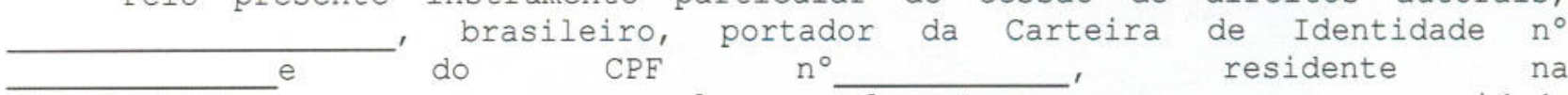

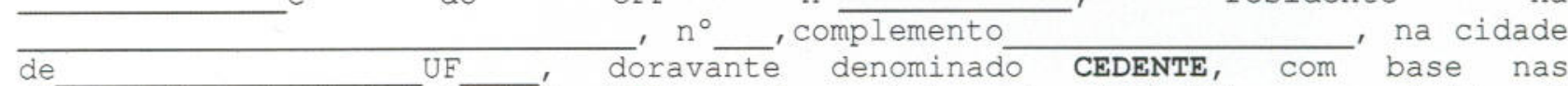
disposições da Lei $9.6 \overline{10 / 9}$, CEDE de forma integral, definitiva e gratuita, à Universidade de Brasilia - UnB, Instituição Federal de Ensino Superior, inscrita no CNPJ sob o n. 00.038.174/0001-43, todos os direitos autorais patrimoniais sobre 0 conteúdo pesquisado e 0 material didático produzido pelo Curso de Especialização em Educação e Patrimônio Cultural, mediante as condições abaixo que, voluntariamente, aceita e outorga:

Cláusula Primeira - A presente cessão de direitos autorais é feita a título gratuito, sem qualquer remuneração ou compensação e possui caráter irrevogável e irretratável.

Cláusula Segunda - A presente cessão de direitos autorais confere à UnB 0 direito de utilizar, no todo ou em parte, o conteúdo pesquisado e o material didático produzido pelo e pelo professor vladimir Corrêa Fonseca , como the aprouver, $\overline{\text { sob }}$ qualquer modalidade, incluindo, mas não se limitando, à reprodução, divulgação, promoção, produção de mídia ou qualquer outro meio, desde que não vedado em Lei.

Cláusula Terceira - A UnB poderá promover quantas edições do material forem necessárias, bem como a sua distribuição no mercado nacional ou exterior.

Cláusula Quarta - o CEDENTE declara que o conteúdo do material produzido, objeto da presente cessão, é de sua exclusiva autoria, sendo titular e detentora dos direitos autorais sobre mesmo, razão pela qual assume inteira responsabilidade por eventual reivindicação desses direitos por parte de terceiros ou questionamentos judiciais ou extrajudiciais decorrentes de sua divulgação.

Cláusula Quinta - A UnB poderá promover o registro do material produzido nos termos do art. 19 da Lei n $9.610 / 1998$.

Cláusula Sexta - A presente cessão de direitos autorais patrimoniais vigorará pelo prazo de 05 (cinco) anos, contados da data de assinatura deste Instrumento, podendo ser renovada pelo CEDENTE, por interesse da UnB.

E assim, por estar de acordo com todas as condições deste Termo de Cessão de Direitos Autorais, firma o presente em duas vias, de igual teor e forma, para um só efeito na presença das testemunhas abaixo.

Nome do responsável
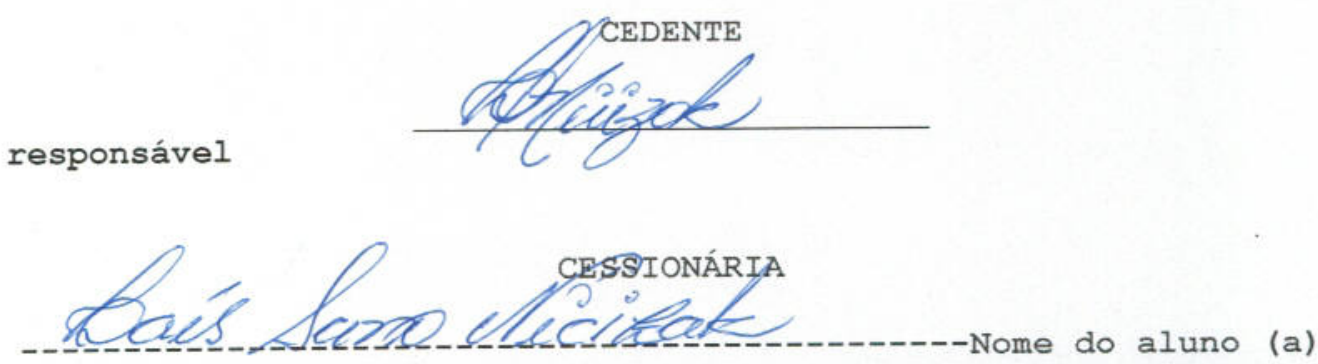

Aluno Pesquisador do Curso de Especialização em Educação e Patrimônio Cultural
(A INTERFACE ENTRE AS ARTES VISUAIS E AS POETICAS DA CENA)

Testemunhas: 
TERMO DE CESSÃO DE DIREITOS AUTORAIS PELO USO DE IMAGEM E ÁUDIO

Pelo presente instrumento particular de cessão de direitos autorais, brasileiro, portador da Carteira de Identidade $n^{\circ}$ do $\quad \mathrm{CPE} \quad \mathrm{n}^{\circ}$ residente na , $n^{\circ}$ , complemento , na cidade

de UF, doravante denominado CEDENTE, com base nas disposições da Lei $9.6 \overline{10 / 98}$, CEDE de forma integral, definitiva e gratuita, à Universidade de Brasilia - UnB, Instituição Federal de Ensino Superior, inscrita no CNPJ sob o n. 00.038.174/0001-43, todos os direitos autorais patrimoniais sobre o conteúdo pesquisado e o material didático produzido pelo Curso de Especialização em Educação e Patrimônio Cultural, mediante as condições abaixo que, voluntariamente, aceita e outorga:

Cláusula Primeira - A presente cessão de direitos autorais é feita a título gratuito, sem qualquer remuneração ou compensação e possui caráter irrevogável e irretratável.

Cláusula Segunda - A presente cessão de direitos autorais confere à UnB 0 direito de utilizar, no todo ou em parte, o conteúdo pesquisado e o material didático produzido pelo e pelo professor vladimir Corrêa Eonseca , como the aprouver, sob qualquer modalidade, incluindo, mas não se limitando, à reprodução, divulgação, promoção, produção de mídia ou qualquer outro meio, desde que não vedado em Lei.

Cláusula Terceira - A UnB poderá promover quantas edições do material forem necessárias, bem como a sua distribuição no mercado nacional ou exterior.

Cláusula Quarta - O CEDENTE declara que o conteúdo do material produzido, objeto da presente cessão, é de sua exclusiva autoria, sendo titular e detentora dos direitos autorais sobre mesmo, razão pela qual assume inteira responsabilidade por eventual reivindicação desses direitos por parte de terceiros ou questionamentos judiciais ou extrajudiciais decorrentes de sua divulgação.

Cláusula Quinta - A UnB poderá promover o registro do material produzido nos termos do art. 19 da Lei n $9.610 / 1998$.

Cláusula Sexta - A presente cessão de direitos autorais patrimoniais vigorará pelo prazo de 05 (cinco) anos, contados da data de assinatura deste Instrumento, podendo ser renovada pelo CEDENTE, por interesse da UnB.

E assim, por estar de acordo com todas as condições deste Termo de Cessão de Direitos Autorais, firma o presente em duas vias, de igual teor e forma, para um só efeito na presença das testemunhas abaixo.

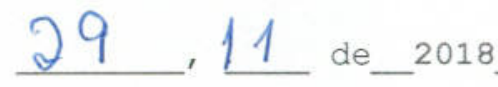

CEDENTE

Nome do responsável
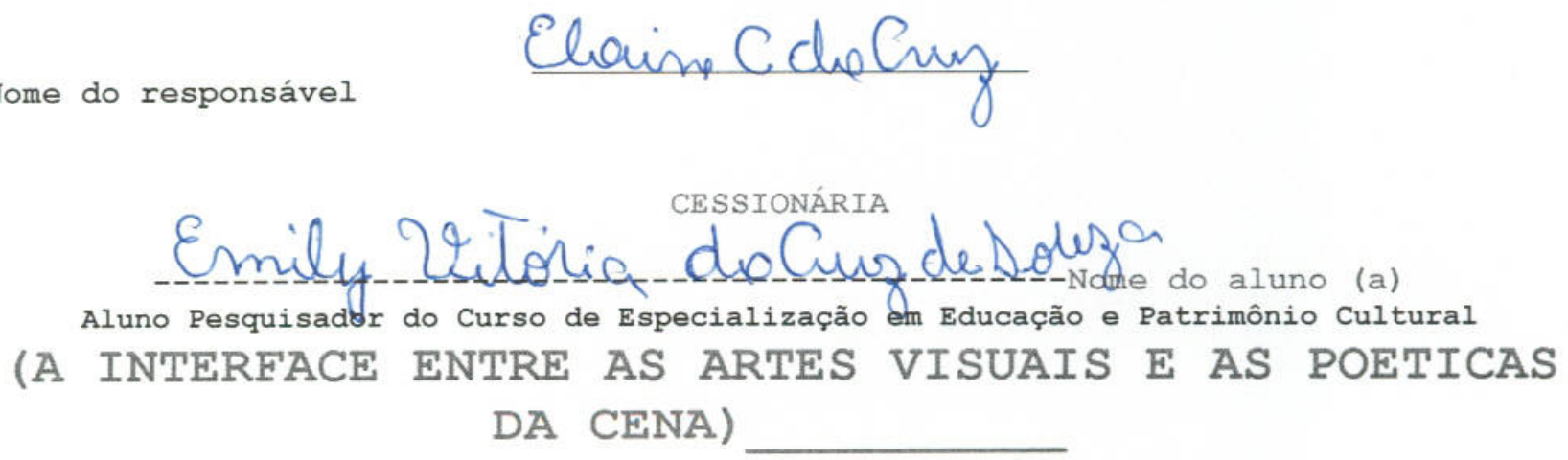

Testemunhas: 
P. pelo presepte instrumento particular de cessão de direitos autorais, Wha Al Cusha brasileiro, portador da Carteira de Identidade n

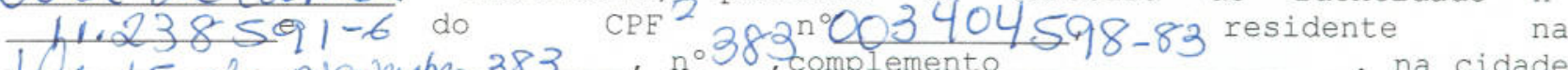

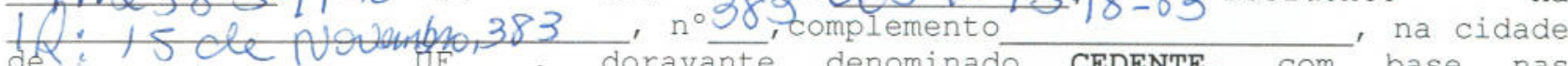
disposições da Lei $9.610 / 98$, doravante denominado CEDENTE, com base nas Universidade de Brasília - UnB, Instituição Federal de Ensino Superior, inscrita no CNPJ sob o n. 00.038.174/0001-43, todos os direitos autorais patrimoniais sobre o conteúdo pesquisado e o material didático produzido pelo Curso de Especialização em Educação e Patrimônio Cultural, mediante as condições abaixo que, voluntariamente, aceita e outorga:

Cláusula Primeira - A presente cessão de direitos autorais é feita a título gratuito, sem qualquer remuneração ou compensação e possui caráter irrevogável e irretratável.

Cláusula Segunda - A presente cessão de direitos autorais confere à UnB o direito de utilizar, no todo ou em parte, o conteúdo pesquisado e o material didático produzido pelo e pelo professor vladimir Corrêa Fonseca , como the aprouver, $\overline{s o b}$ qualquer modalidade, incluindo, mas não se limitando, à reprodução, divulgação, promoção, produção de mídia ou qualquer outro meio, desde que não vedado em Lei.

Cláusula Terceira - A UnB poderá promover quantas edições do material forem necessárias, bem como a sua distribuição no mercado nacional ou exterior.

Cláusula Quarta - O CEDENTE declara que o conteúdo do material produzido, objeto da presente cessão, é de sua exclusiva autoria, sendo titular e detentora dos direitos autorais sobre mesmo, razão pela qual assume inteira responsabilidade por eventual reivindicação desses direitos por parte de terceiros ou questionamentos judiciais ou extrajudiciais decorrentes de sua divulgação.

Cláusula Quinta - A UnB poderá promover o registro do material produzido nos termos do art. 19 da Lei $n^{\circ} 9.610 / 1998$.

Cláusula Sexta - A presente cessão de direitos autorais patrimoniais vigorará pelo prazo de 05 (cinco) anos, contados da data de assinatura deste Instrumento, podendo ser renovada pelo CEDENTE, por interesse da UnB.

E assim, por estar de acordo com todas as condições deste Termo de Cessão de Direitos Autorais, firma o presente em duas vias, de igual teor e forma, para um só efeito na presença das testemunhas abaixo. de 2018

Nome do responsável

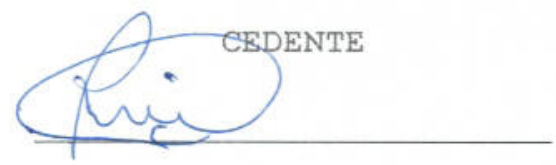




\section{TERMO DE CESSÃO DE DIREITOS AUTORAIS PELO USO DE IMAGEM E ÁUDIO}

Pelo presente instrumento particular de cessão de direitos autorais, brasileiro, portador da Carteira de Identidade $n^{\circ}$ do $\quad \mathrm{CPE} \mathrm{n}^{\circ}$ , n ${ }^{\circ}$ , complemento residente

na

e do $\mathrm{CPE} \mathrm{n}^{\circ}, \mathrm{n}^{\circ}$, complemento $^{\prime}$, na cidade
de UF_, doravante denominado CEDENTE, com base nas disposições da Lei $9.6 \overline{10 / 98}$, CEDE de forma integral, definitiva e gratuita, à Universidade de Brasilia - UnB, Instituição Federal de Ensino Superior, inscrita no CNPJ sob o n. 00.038.174/0001-43, todos os direitos autorais patrimoniais sobre 0 conteúdo pesquisado e o material didático produzido pelo Curso de Especialização em Educação e Patrimônio Cultural, mediante as condições abaixo que, voluntariamente, aceita e outorga:

Cláusula Primeira - A presente cessão de direitos autorais é feita a título gratuito, sem qualquer remuneração ou compensação e possui caráter irrevogável e irretratável.

Cláusula Segunda - A presente cessão de direitos autorais confere à UnB 0 direito de utilizar, no todo ou em parte, o conteúdo pesquisado e o material didático produzido pelo e pelo professor vladimir Corrêa Fonseca $\quad$ como the aprouver, $\overline{\text { sob }}$ qualquer modalidade, incluindo, mas não se limitando, à reprodução, divulgação, promoção, produção de mídia ou qualquer outro meio, desde que não vedado em Lei.

Cláusula Terceira - A UnB poderá promover quantas edições do material forem necessárias, bem como a sua distribuição no mercado nacional ou exterior.

Cláusula Quarta - O CEDENTE declara que o conteúdo do material produzido, objeto da presente cessão, é de sua exclusiva autoria, sendo titular e detentora dos direitos autorais sobre mesmo, razão pela qual assume inteira responsabilidade por eventual reivindicação desses direitos por parte de terceiros ou questionamentos judiciais ou extrajudiciais decorrentes de sua divulgação.

Cláusula Quinta - A UnB poderá promover o registro do material produzido nos termos do art. 19 da Lei n $9.610 / 1998$.

Cláusula sexta - A presente cessão de direitos autorais patrimoniais vigorará pelo prazo de 05 (cinco) anos, contados da data de assinatura deste Instrumento, podendo ser renovada pelo CEDENTE, por interesse da UnB.

E assim, por estar de acordo com todas as condições deste Termo de Cessão de Direitos Autorais, firma o presente em duas vias, de igual teor e forma, para um só efeito na presença das testemunhas abaixo.

CEDENTE

Nome do responsável $\propto$
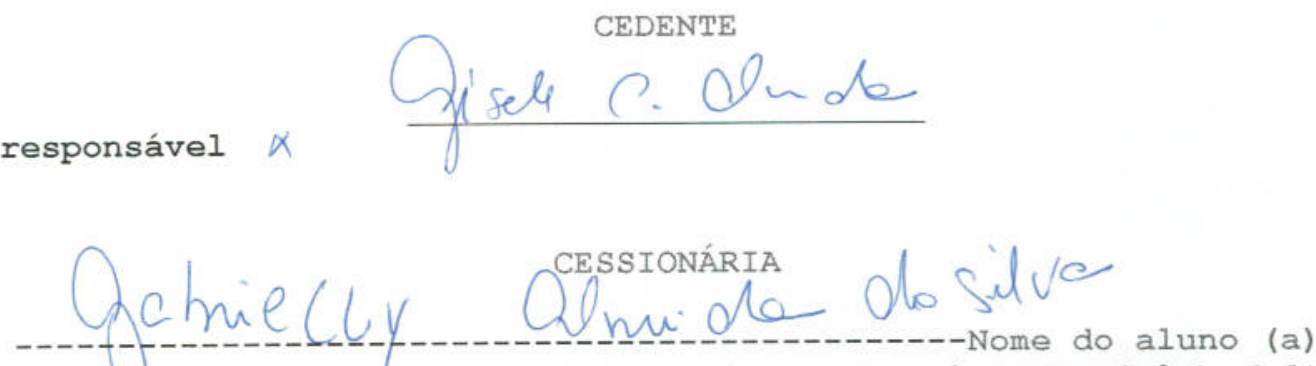

Aluno Pesquisador do Curso de Especialização em Educação e Patrimônio Cultural

(A INTERFACE ENTRE AS ARTES VISUAIS E AS POETICAS DA CENA)

Testemunhas: 